\title{
Interrogating the Liberal Peace in East Timor
}

By Margaret Behrend

\begin{abstract}
A Thesis
Submitted to the Victoria University of Wellington in Partial Fulfilment of the Requirements for the Degree of Master of International Relations (MIR)
\end{abstract}

School of History, Philosophy, Political Science and International Relations

Victoria University of Wellington

2011 


\section{Table of Contents}

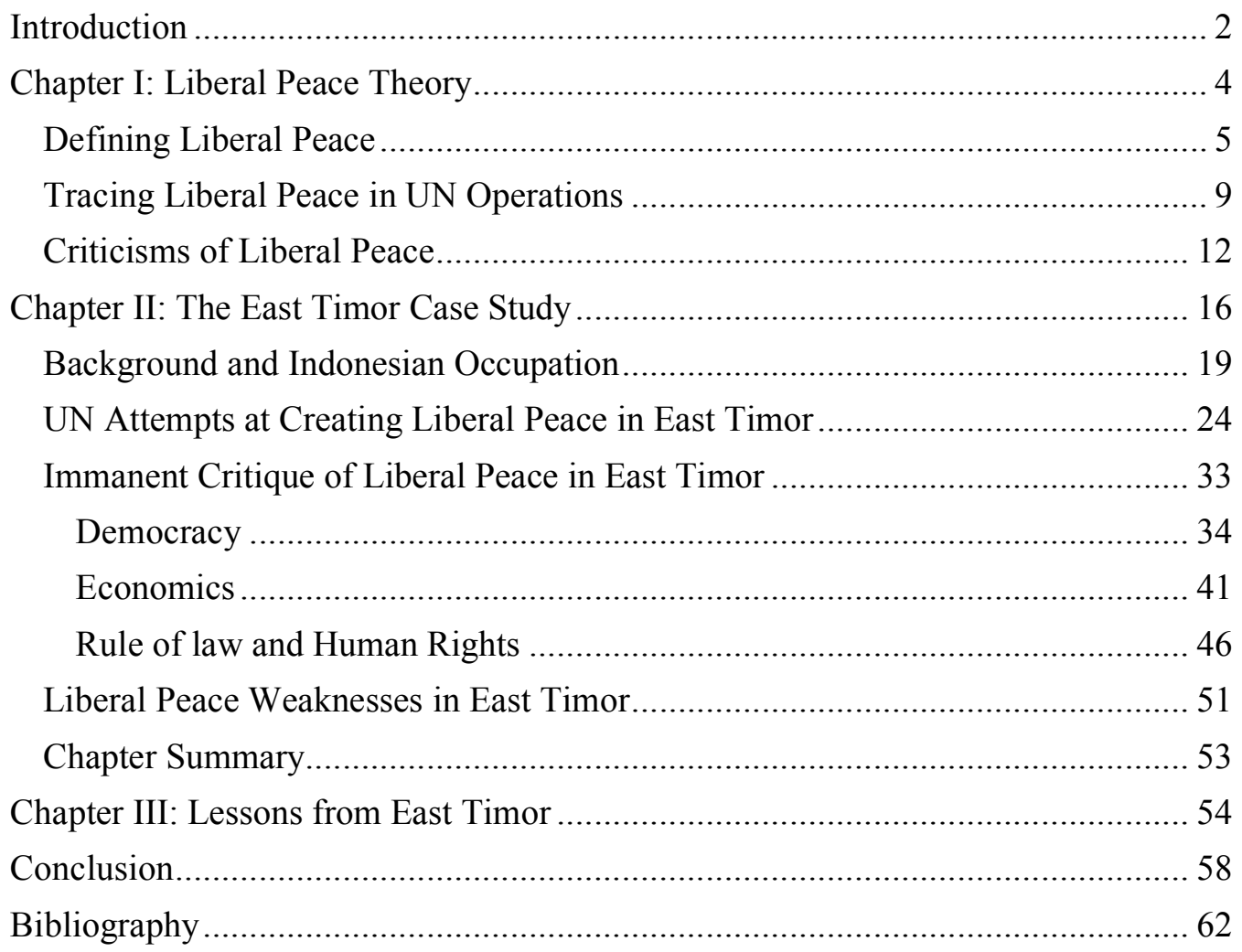




\section{Introduction}

Peace operations from the 1990s have increasingly been driven by the assumption that conflict and social unrest can be 'solved' through the establishment and support of liberal structures. Known academically as liberal peace, this approach advocates the liberalisation of politics and economics, and the establishment of rule of law and international human rights norms, claiming such liberal structures offer the necessary foundation to lasting peace. This claim has become unquestioned logic for many of the international bodies and individual actors that participate in the peace industry and has led to a standardised approach to post-conflict situations. However, is this "peacebuilding consensus"1 justified? Does liberal peace foster sustainable peace?

This thesis interrogates the concept and application of liberal peace to assess the extent to which liberal peacebuilding delivers on its claims and provides the foundations of sustainable peace. Due to the enormous size of such a project and the limitations of this thesis, I focus on one case study in my analysis of the liberal peace approach - East Timor. Relying on a single example of peacebuilding allows for a more in depth discussion of efforts, however, it is insufficient to draw broader conclusions about liberal peace. This body of research, therefore, is intended to contribute to existing academic work that evaluates liberal peace. Where this thesis deviates from existing research, however, is in the application of an immanent critique to assess liberal peacebuilding in East Timor.

East Timor was selected as the case study because the mission was one of the most extensive peacebuilding efforts by the international community, ${ }^{2}$ yet East Timor has not emerged as a strong and stable state. ${ }^{3}$ The operation was a classic example of liberal peacebuilding which focused on creating or reforming structures in East Timor that, according to liberal peace logic, would support lasting peace. From 1999

1 Oliver P. Richmond and Jason Franks, Liberal Peace Transitions: Between Statebuilding and Peacebuilding (Edinburgh: Edinburgh University Press, 2009), 9.

2 Jarat Chopra, "Building State-Failure in East Timor," Development and Change 33, no. 5 (2002): 981.

${ }^{3}$ Ibid.: 999. 
to 2002, the United Nations (UN) administered East Timor, and with the support of international donors and other agencies, assisted East Timor in its transition to independence. Following free and fair elections in 2001 and 2002, the UN announced the conclusion of its administration mission and the success of the project. In early 2006, the World Bank reiterated East Timor's successful transformation - praising the infrastructure, government and economic activity. ${ }^{4}$ Yet, within weeks of the World Bank's positive evaluation, violence had broken out on the streets of Dili and other urban centres.

My research focuses on the claims of liberal peace, how successful liberal peace efforts are in practice, and gauging what effect they have on long term peace prospects. In my evaluation of liberal peace and the analysis of peacebuilding efforts in East Timor, I make two main arguments. First, despite the prevalence of liberal peace and its uncritical application by international actors in post-conflict situations, introducing or reforming liberal structures do not automatically foster lasting peace. Indeed, a liberal peace approach can exacerbate social tensions and contribute to renewed violence, or fail to prevent a relapse of fighting. Second, despite weaknesses, I further argue that a liberal approach to peace has merit and the potential to foster durable peace, therefore, liberal peace should be reformed to become a more nuanced and culturally responsive form of peacebuilding.

This thesis is divided into four chapters. Chapter I introduces liberal peace as a discourse and normative framework. The chapter then traces the emergence and dominance of liberal peace in UN peace operations before identifying some of the general criticisms of the approach. Chapter II moves on to the particular case study of East Timor. It begins with a brief introduction to East Timor, then discusses the aims of the United Nations Transitional Administration in East Timor (UNTAET) mission in relation to the objectives of liberal peace before employing an immanent critique to evaluate the liberal peace efforts. The specific issues of liberal peace in East Timor are then related the general criticisms laid out in Chapter I. Chapter III makes the case for liberal peace reform, presenting a number of recommendations.

4 World Bank, "Closing Press Conference in Timor-Leste with Paul Wolfowitz," http://go.worldbank.org/XOGCSIM1H0 (accessed 07 February 2011). 
The final chapter offers a summary of the thesis and a brief discussion of the challenges for liberal peace reform.

Before continuing, however, an important note must be made. Throughout this thesis, the English name of East Timor is intentionally used rather than the official Portuguese name of Timor-Leste. The naming of the newly independent state and the selection of national languages has proven contentious. Despite an estimated population of around 1.1 million people, ${ }^{5}$ East Timor is host to 16 language varieties and numerous dialects. ${ }^{6}$ At independence the government announced the national languages would be Tetum, the most commonly spoken indigenous language, and Portuguese, the language of dissent among rebels. This decision was controversial as neither language is spoken by a majority; but while Tetum became a symbolic unifying language under Indonesian rule, ${ }^{7}$ Portuguese has historical links to oppression and colonialism, and is only spoken by an elite minority. ${ }^{8}$ Rather than engage in the debate over language, therefore, the neutral English name East Timor is used. ${ }^{9}$

\section{Chapter I: Liberal Peace Theory}

The purpose of this research paper is to interrogate liberal peace both generally and in specific relation to East Timor. This chapter provides an overview of the concept of liberal peace. It is divided into three sections. The first section defines liberal peace as a framework and a discourse informing contemporary peace operations. At its core, liberal peace holds liberal structures foster lasting peace. The second section of this chapter traces the rise of liberal peace in UN operations. The final section

\footnotetext{
52009 estimate. — "Timor-Leste Data," http://data.worldbank.org/country/timor-leste (accessed 20 January 2011).

${ }^{6}$ Kerry Taylor-Leech, "Sustaining Language Policy and Language Rights: Where to from Here," in East Timor: Beyond Independence, ed. Damien Kingsbury and Michael Leach (Clayton: Monash University Press, 2007), 239.

${ }^{7}$ Sven Gunnar Simonsen, "The Authoritarian Temptation in East Timor: Nationbuilding and the Need for Inclusive Governance," Asian Survey 46, no. 4 (2006): 584-85.

8 Damien Kingsbury, "Political Development," in East Timor: Beyond Independence, ed. Damien Kingsbury and Michael Leach (Clayton: Monash University Press, 2007), 23.

${ }^{9}$ Oliver P. Richmond and Jason Franks, "Liberal Peacebuilding in Timor Leste: The Emperor's New Clothes?," International Peacekeeping 15, no. 2 (2008): 199.
} 
briefly outlines some of the general criticism of liberal peace. This chapter introduces the key principles and criticisms of liberal peace which are used to assess efforts in East Timor in Chapters II.

\section{Defining Liberal Peace}

This section gives an introduction to liberal peace. Liberal peace is an approach to conflict that is grounded in liberal and neo-liberal theory and tradition. It assumes that liberal structures provide the foundations for sustainable peace, and claims creating or reforming political, economic, judicial and social structures to liberal standards will foster lasting peace. Liberal peace is a tripartite discourse which results in three models of peacebuilding praxis: conservative or statebuilding; orthodox or democratic; and emancipatory or civil society. ${ }^{10}$ Each discourse endorses different methods for peacebuilding, while still ascribing to the assumption that liberal structures will foster self-sustaining peace.

Competing and overlapping definitions of liberal peace can be found in international relations literature. For the purpose of this research, liberal peace is both a framework and a discourse which guides modern peace operations. Oliver Richmond and Jason Franks define liberal peace as a "normative framework", ${ }^{11}$ that is, it is a model for approaching conflict and post-conflict situations which employs liberal or neo-liberal standards. Liberalism and neo-liberalism are founded on the principle of freedom. ${ }^{12}$ Defence or protection of individual freedom has led to the development of a series of rights and institutions fundamental to liberal theory, including positive and negative freedoms, democratic representation, constitutionalism, equality before the law, private property, and the free market. ${ }^{13}$

\footnotetext{
${ }^{10}$ Oliver P. Richmond, "The Problem of Peace: Understanding the 'Liberal Peace'," Conflict, Security and Development 6, no. 3 (2006). And John Heathershaw, "Unpacking the Liberal Peace: The Dividing and Merging of Peacebuilding Discourses," Millennium 36, no. 3 (2008).

${ }^{11}$ Oliver P. Richmond and Jason Franks, "Liberal Hubris? Virtual Peace in Cambodia," Security Dialogue 38, no. 1 (2007): 27-28.

${ }^{12}$ Michael W. Doyle, "Liberalism and International Relations," in Kant and Political Philosophy: The Contemporary Legacy, ed. Ronald Beiner and William James Booth (New Haven: Yale University Press, 1993), 173.

${ }^{13}$ Ibid., 173-74.
} 
The liberal peace approach attempts to foster peace by introducing a number of these norms and institutions. According to proponents of the approach, long standing peaceful relations between liberal states and the low rate of internal conflict ${ }^{14}$ indicate durable peace is achievable through the creation of an effective liberal state. ${ }^{15}$ Liberal peace, therefore, has a two-pronged approach to conflict which entails not just ending violence, but also repairing or creating structures that meet liberal standards ${ }^{16}$ and, it is assumed, will support peace. In particular, the approach endorses the democratisation of government, the marketisation of the economy, the establishment of rule of law, the development of human rights, and in some instances the promotion of neo-liberal development. ${ }^{17}$ This robust conceptualisation of peace, distinguishes liberal peace from traditional approaches to conflict, which consider the absence of fighting to be a sufficient form of peace. ${ }^{18}$

Although liberal peace is the dominant framework informing peace operations, the approach is not neutral. The claim of liberal peace that democracy, free markets, rule of law and human rights will engender peace has been largely accepted by western states, the international institutions that respond to crises, and the professionals employed to build peace. ${ }^{19}$ However, the framework promotes particular models of political, economic, legal, and social arrangements and in doing so it privileges a liberal perspective. ${ }^{20}$ Where structures do not fit with liberal standards, the approach advocates the transfer of liberal models and the reorganisation of society. Mac Ginty summarises liberal peace as:

the concept, condition and practice whereby leading states, international organizations and international financial institutions promote their version of peace through peace-support interventions, control of

\footnotetext{
${ }^{14}$ Roland Paris, At War's End: Building Peace after Civil Conflict (Cambridge: Cambridge University Press, 2004), 42.

15 Stein Sundstøl Eriksen, "The Liberal Peace Is Neither: Peacebuilding, State Building and the Reproduction of Conflict in the Democratic Republic of Congo," International Peacekeeping 16, no. 5 (2009). 660 and 662

${ }^{16}$ Richmond and Franks, "Liberal Peacebuilding in Timor Leste: The Emperor's New Clothes?," 187.

${ }^{17}$ Roger Mac Ginty and Oliver P. Richmond, "Myth or Reality: Opposing Views on the Liberal Peace and Post-War Reconstruction," Global Society 21, no. 4 (2007): 491. See also Paris, At War's End: Building Peace after Civil Conflict, 19. See also Richmond and Franks, Liberal Peace Transitions: Between Statebuilding and Peacebuilding, 4.

${ }^{18}$ Michael Mandelbaum, The Ideas That Conquered the World: Peace Democracy, and Free Markets in the Twenty-First Century (New York: Public Affairs, 2002), 244.

${ }_{19}$ Richmond and Franks, Liberal Peace Transitions: Between Statebuilding and Peacebuilding, 9.

20 Heathershaw, "Unpacking the Liberal Peace: The Dividing and Merging of Peacebuilding Discourses," 606.
} 
international financial architecture, support for state sovereignty and the international status quo. ${ }^{21}$

Liberal peace is informed by a history of political theory and debates concerning peace. ${ }^{22}$ These debates have led to three models or discourse of liberal peace in practice, known as conservative, orthodox and emancipatory by Richmond, or as statebuilding, democratic peacebuilding, and civil society peacebuilding by Heathershaw. Yet despite different methods or techniques employed by each model or discourse, the objective continues to be the establishment of liberal structures upon which durable peace will develop. Each of these models or discourses is considered in turn.

The conservative model of peace, or Heathershaw's peacebuilding through statebuilding, is a top down approach to constructing liberal peace which often employs coercive methods to achieve its goal of establishing liberal structures, particularly democratic governance and rule of law. ${ }^{23}$ This may involve military intervention and the use of force, or subtler techniques of diplomacy and conditionality. ${ }^{24}$ Consequently, the model primarily involves military actors and state elites. $^{25}$ This model of peacebuilding is reliant on ongoing support from donors and other external actors. ${ }^{26}$

Orthodox or democratic peacebuilding is a more moderate model of liberal peace. This model or discourse is influenced by constitutional and institutional concepts of peace found in international relations theory, ${ }^{27}$ and is directed at developing human rights, constitutionalism and property rights. ${ }^{28}$ It draws a range of actors for support, including regional and international organisations, and non-governmental agencies.

${ }^{21}$ Roger Mac Ginty, "Indigenous Peace-Making Versus the Liberal Peace," Cooperation and Conflict 43, no. 2 (2008): 143.

${ }^{22}$ For a detailed discussion see Richmond, "The Problem of Peace: Understanding the 'Liberal Peace'."

${ }^{23}$ Heathershaw, "Unpacking the Liberal Peace: The Dividing and Merging of Peacebuilding Discourses," 619.

${ }^{24}$ Richmond and Franks, "Liberal Hubris? Virtual Peace in Cambodia," 29-30. And Richmond, "The Problem of Peace: Understanding the 'Liberal Peace'," 297.

${ }^{25}$ Richmond, "The Problem of Peace: Understanding the 'Liberal Peace'," 297.

${ }^{26}$ Richmond and Franks, "Liberal Hubris? Virtual Peace in Cambodia," 30.

${ }^{27}$ For a discussion of constitutional and institutional peace, see Richmond, "The Problem of Peace: Understanding the 'Liberal Peace'," 293.

28 Heathershaw, "Unpacking the Liberal Peace: The Dividing and Merging of Peacebuilding Discourses," 619. 
While some efforts are made to include the population and cultivate local ownership, this approach is still more directed at engaging with elites and some mid level actors than interacting with those at the grassroots level. ${ }^{29}$

The final discourse of liberal peace Richmond and Heathershaw identify is the emancipatory model, or civil society peacebuilding. Richmond holds the emancipatory model is informed by a more critical expression of liberal peace. It is distinguishable from the conservative and orthodox models in its greater emphasis on engaging with the local community and the diminished importance of the state. Consequently, the key players in the emancipatory model of liberal peace are local actors at the grassroots level. ${ }^{30}$ This model is directed at creating civil peace and is concerned with issues of justice, welfare, reconciliation and interpersonal relationships. ${ }^{31}$ While the emancipatory model is more critical than the other models of peace, it is still a liberal peace discourse which holds liberalism is universal; nevertheless, it also recognises the role of negotiation in the peace process. ${ }^{32}$

While the gradations and discourses of liberal peace have been identified and defined, these categories are not fixed, particularly in liberal peace praxis. The conservative, orthodox and emancipatory models contain contradictory or opposing elements; however, in practice two or more of the models may be present to a varying extent during a single intervention. ${ }^{33}$ Indeed, the nature of the conflict or post-conflict situation at any given time affects the model of liberal peace employed - during times of heavy fighting, coercion may be more effective, while the orthodox and emancipatory models need greater stability for success. Heathershaw contends that merging between the models is so extensive that is difficult to separate the individual discourses. ${ }^{34}$ At times, all three discourses may combine in a metadiscourse in which the contestations between the individual discourses increase an operation's dynamism. ${ }^{35}$

\footnotetext{
${ }^{29}$ Richmond and Franks, Liberal Peace Transitions: Between Statebuilding and Peacebuilding, 8.

${ }^{30}$ Richmond, "The Problem of Peace: Understanding the 'Liberal Peace'," 301.

31 Heathershaw, "Unpacking the Liberal Peace: The Dividing and Merging of Peacebuilding Discourses," 607-08.

${ }^{32}$ Richmond, "The Problem of Peace: Understanding the 'Liberal Peace'," 301.

33 Ibid.

34 Heathershaw, "Unpacking the Liberal Peace: The Dividing and Merging of Peacebuilding Discourses," 607.

${ }^{35}$ Ibid.: 620 .
} 
Liberal peace is therefore a normative framework which is comprised of a series of peace models and corresponding discourses; however, the objective of liberal peace remains the creation of a liberal society ${ }^{36}$ which will support sustainable peace. ${ }^{37}$ Liberal peace attempts to build a liberal state through the reformation, creation, or liberalisation of social structures. In particular, liberal peacebuilding targets four areas: governance, the economy, rule of law, and human rights, and attempts to transform these into structures that conform to neo-liberal ideals. ${ }^{38}$

To summarise, this section has defined the concept of liberal peace as both a normative framework and tripartite discourse. It has shown that liberal peace has a number of expressions which may overlap or become blurred in practice. However, the founding claim of liberal peace, present in each discourse, is that liberal structures foster lasting peace. It is this claim that I assess in Chapter II by employing an immanent critique. First, however, I briefly outline the rise of the liberal peace framework in UN peace missions to demonstrate liberal peace has increasingly become the standard blueprint for peace operations.

\section{Tracing Liberal Peace in UN Operations}

This section traces the evolution of UN peace operation to demonstrate the increasing dominance of the liberal peace framework. UN peace operations expanded from limited missions with pragmatic goals and restrictive principles during the Cold War, to robust missions with the ambitious goal of establishing sustainable peace following the collapse of the Soviet Union. In accordance with the liberal peace framework, lasting peace was held to be founded on democracy, good governance, free markets, the rule of law, and human rights. Peace operations from the $1990 \mathrm{~s}$, therefore, began to place great importance on cultivating these elements in post-conflict areas.

\footnotetext{
${ }^{36}$ Eriksen, "The Liberal Peace Is Neither: Peacebuilding, State Building and the Reproduction of Conflict in the Democratic Republic of Congo," 662.

${ }^{37}$ Richmond and Franks, "Liberal Peacebuilding in Timor Leste: The Emperor's New Clothes?," 187.

${ }^{38}$ Ibid.
} 
Peace operations prior to the 1990s were not directed at establishing liberal foundations to support sustainable peace. Contemporary operations informed by liberal peace, regardless of the particular model, have a robust blueprint for managing conflict or post-conflict scenarios which prescribes the liberalisation of political, economic, legal, and social sectors of society. During the Cold War, peace missions were shaped by the dominant ideology of the period and the reality of the superpower standoff. Operations pragmatically aimed to establish negative peace ${ }^{39}$ and prevent superpower involvement which could escalate minor conflicts into proxy wars. Sustainable peace was dismissed as utopian, and operations were limited to monitoring ceasefires and troop withdrawals ${ }^{40}$ with the consent of all involved parties while remaining impartial. ${ }^{41}$

Competition between the superpowers also complicated any discussion of what the internal institutions of a state should look like. The UN could not have advocated a particular form of governance as the "right" model to use because the US and USSR each promoted their own brand of governance. ${ }^{42}$ The US advocated liberal democracy which emphasised political rights and the importance of elections. The Soviet Union also promoted their own brand of democracy - 'people's democracy' which was characterised by public ownership and governance by a communist party for the benefit of the population. ${ }^{43}$ Similarly, the US and USSR would not agree on the "right" economic system. The UN, therefore, avoided issues of domestic arrangements in its missions.

The end of the Cold War and the fall of the USSR were celebrated as a triumph of liberalism, and without any serious competition, liberalism quickly became the dominant global ideology. According to Heathershaw, the end of the Cold War and the associated newfound optimism were prompted by a "reductive and teleological informed reading of the significance of 1989". ${ }^{4}$ The collapse of the Soviet Union

\footnotetext{
${ }^{39}$ Marrack Goulding, "The Evolution of U.N. Peacekeeping " International Affairs 69, no. 3 (1993): 456.

${ }^{40}$ Paul F. Diehl, Peace Operations (Cambridge: Polity Press, 2008), 44.

${ }^{41}$ Ibid., 57.

${ }^{42}$ Paris, At War's End: Building Peace after Civil Conflict, 15.

43 Ibid.

44 Heathershaw, "Unpacking the Liberal Peace: The Dividing and Merging of Peacebuilding Discourses," 600 .
} 
was viewed as evidence of liberalism's superiority, and liberalisation was thus increasingly offered, and accepted, as the solution to a variety of social ills. ${ }^{45}$ The faith in liberalism and liberalisation began to find their way into peace operations.

The fall of the USSR removed liberalism's only serious ideological competition and liberal ideals concerning government and economics began to spread from their western hub around the world. Without a major rival, the US liberal model of governance was increasingly accepted internationally and from the early to mid 1990 s, the number of liberal democracies rose significantly as states, particularly from the former Soviet bloc, introduced democratic constitutions. ${ }^{46}$ Similarly on the economic front, liberal market economics also began to spread with the fall of the USSR. Like liberal democracy, the liberal economic system was left without any major ideological competition with the end of the Cold War and quickly became the dominant model for economics. Claude Ake contends that market economics came "close to global theology" 47 as much of the world rushed to adopt liberal principles after the fall of the Soviet Union. ${ }^{48}$ Even communist states such as China began to liberalise elements of their economies. ${ }^{49}$

Liberal ideology began to influence institutions, including the UN whose own peace operations began to adopt a liberal peace framework. In 1992, Boutros-Ghali released 'An Agenda for Peace' which detailed the new robust approach UN peace operations should have and advocated the use of a liberal peace framework. In the document, Boutros-Ghali emphasises the importance of the UN's involvement at different stages of a conflict. Before violence erupts, preventative diplomacy can ease tensions and potentially avert a crisis; during a conflict, peacemaking and peacekeeping can hasten a peace settlement and protect peace once established; and after fighting ceases, there is a role for the UN in peacebuilding. ${ }^{50}$ Boutros-Ghali

${ }^{45}$ Paris, At War's End: Building Peace after Civil Conflict, 19-20.

${ }^{46}$ Ibid., 20. See also Mandelbaum, The Ideas That Conquered the World: Peace Democracy, and Free Markets in the Twenty-First Century, 251-52.

${ }^{47}$ Quoted in Paris, At War's End: Building Peace after Civil Conflict, 22.

48 Ibid., 21.

${ }^{49}$ Mandelbaum, The Ideas That Conquered the World: Peace Democracy, and Free Markets in the Twenty-First Century, 284.

${ }^{50}$ Boutros Boutros-Ghali, An Agenda for Peace: Preventative Diplomacy, Peacemaking and PeaceKeeping, Report of the Secretary-General Pursuant to the Statement Adopted by the Summit Meeting of the Security Council on 31 January 1992 (New York: United Nations, 1992). Para 20 
coined the term peacebuilding which he defined as "action to identify and support structures which will tend to strengthen and solidify peace in order to avoid a relapse into conflict." 51

It is in peacebuilding that the liberal peace framework is most evident as the structures to be supported correspond to the key elements of liberal peace. 'An Agenda for Peace' recognises the causes of war are diverse and argues that international response must go beyond addressing the military issues. ${ }^{52}$ In particular, Boutros-Ghali argues peacebuilding must advance political democracy, establish order, ${ }^{53}$ foster economic development, and improve human rights. ${ }^{54}$ These recommendations for consolidating peace directly align with the objectives of liberal peace.

Overall, this section has briefly traced the rise of liberalism internationally and the dominance of a liberal peace framework in UN peace operations following the end of the Cold War. Early UN missions were constrained by the superpower rivalry and guided by pragmatic but limited goals without reference to liberal peace. Conversely, UN peace operations in the early 1990s were affected by the supposed triumph of liberalism and the newfound optimism of the period. Declarations were made to broaden the UN's scope and promote sustainable peace. As key UN documents show, the new style of peace operations was underwritten by a liberal peace framework and greater importance was placed on fostering sustainable peace balanced on key structures of liberal societies. Next, some of the general criticisms of liberal peace are introduced.

\section{Criticisms of Liberal Peace}

Despite becoming the dominant discourse shaping peace operations since the 1990s, liberal peace is contested. This section highlights some of the criticisms of the methodology of liberal peace. Among the common criticisms is that liberal peace is

\footnotetext{
${ }^{51}$ Ibid. Para 21

52 Ibid.Para 13

${ }^{53}$ Ibid. Para 55

${ }^{54}$ Ibid. Para 5
} 
potentially destabilising, that reforms may turn populations against liberalisation, and that the approach is neo-colonial, inconsiderate of cultural specificities and too formulaic. These criticisms question the methods of liberal peace and in doing so also question the extent to which liberal peace is capable of delivering its claim of fostering durable peace.

Liberal peace claims to cultivate sustainable peace, however, critics accuse the approach of utilising methods which are potentially destabilising. ${ }^{55}$ Liberal peace advocates democratic reform and marketisation because liberal democracies have been shown to be more peaceful internally and in their international relations with other liberal states. ${ }^{56}$ However, while mature liberal democracies may be peaceful, the processes of transforming to a democracy and market economy can be destabilising in states still recovering from conflict, ${ }^{57}$ particularly when such changes are pushed through in short timeframes.

Liberal peace emphasises the importance of democratic governance and free and fair elections, however, the transformation to democracy and the holding of elections can increase tension and disrupt reconciliation, particularly if the society lacks institutions and an active civil society. Political competition is necessary for democratic elections; however, in states still recovering from conflict without a history of popular participation, political competition can ignite political differences among opponents and reinforce divisions within the community. ${ }^{58}$ Snyder argues if elites feel democratisation threatens their position, there is a strong incentive to incite belligerent nationalism to maintain their position. ${ }^{59}$ Nationalism constructs ingroup and outgroup divisions, solidifying differences rather than fostering reconciliation. ${ }^{60}$ The divisive effect of elections is evident in the Bosnian elections in 1996, in which the population voted along ethnic lines for extremist parties, rather

55 See Roland Paris, "Peacebuilding and the Limits of Liberal Internationalism," International Security 22, no. 2 (1997): 56. Charles-Philippe David, "Does Peacebuilding Build Peace? Liberal (Mis)Steps in the Peace Process," Security Dialogue 30, no. 1 (1999): 33-34. Paris, At War's End: Building Peace after Civil Conflict.

${ }^{56}$ Paris, At War's End: Building Peace after Civil Conflict, 42.

57 _

${ }^{58}$ David, "Does Peacebuilding Build Peace? Liberal (Mis)Steps in the Peace Process," 33-34.

59 Jack Snyder, From Voting to Violence: Democratization and Nationalist Conflict (New York: Norton, 2000), 32.

${ }^{60}$ Ibid., 70 . 
than for more moderate parties. ${ }^{61}$ Neutral institutions have the potential to overcome social cleavages through the regulation of competition, support of civil society, and promotion of unity. ${ }^{62}$ Liberal peace, though, focuses more on elections than on building the necessary institutions that will sustain democracy.

Economic reforms endorsed by liberal peace also have the potential to be highly destabilising. The restructuring of post-conflict economies at the behest of the Bretton Woods institutions focuses primarily on the recovery of the economy while the effect these reforms may have on the population is a secondary consideration. ${ }^{63}$ The restructuring recommended by international financial institutions generally include privatisation of state assets, ending state intervention in the economy, eliminating any hurdles to trade and foreign direct investment, and minimising government spending overall. ${ }^{64}$ These reforms may have detrimental effects on the population as the economy contracts in the short term, lowering wages, increasing unemployment rates, and decreasing the value of the local currency while concomitantly pushing up the costs of imported goods. ${ }^{65}$ These reforms fall heaviest on the most disadvantaged in society, increasing inequality and potentially aggravating social tensions. ${ }^{66}$

Harsh economic conditions may also jeopardise popular support for peace. Where peace is coupled with improvements in living conditions, the population experiences a 'peace dividend', or a reward for peace. As a result, the peace process is more likely to experience widespread support and spoilers are less tolerated by ordinary citizens. ${ }^{67}$ Conversely, when austerity measures and a decline in standards of living accompany the liberal peace process, there may be less popular support for the process and the peace created. ${ }^{68}$ Such conditions can also create an incentive for elites to undermine liberalisation and introduce populist policies that protect local

${ }^{61}$ Paris, At War's End: Building Peace after Civil Conflict, 100-01.

${ }^{62}$ Edward D. Mansfield and Jack L. Snyder, "The Sequencing 'Fallacy'," Journal of Democracy 18, no. 3 (2007): 7.

${ }^{63}$ David, "Does Peacebuilding Build Peace? Liberal (Mis)Steps in the Peace Process," 35.

${ }^{64}$ Paris, At War's End: Building Peace after Civil Conflict, 166.

65 Ibid.

${ }^{66}$ David, "Does Peacebuilding Build Peace? Liberal (Mis)Steps in the Peace Process," 36.

${ }^{67}$ Paris, At War's End: Building Peace after Civil Conflict, 200.

${ }^{68}$ Ibid. 
producers and markets, while maintaining their authority, similarly threatening peace and liberalism. ${ }^{69}$

Liberal peace is also criticised for being neo-colonial and for lacking cultural understanding. Liberal peace has been accused of neo-colonialism because it attempts to transfer Western models of governance, markets and social organisation to non-Western contexts. Liberal peace, in each of its discourses, involves intervention by a third party and the introduction of foreign standards and ideas of peace in a host community. ${ }^{70}$ This focus on reform and foreign standards, some critics argue, makes liberal peace modern day civilisation mission. ${ }^{71}$ Furthermore, liberal peace is the dominant discourse on peace, drowning out local voices. ${ }^{72}$ Proponents of liberal peace believe in the framework's universality and, therefore, are quick to reject local non-liberal alternatives. ${ }^{73}$ Liberal peace thus preaches international 'best practices', rather than engaging with local structures. ${ }^{74}$ However, critics argue liberal structures will only become embedded and self-sustainable if they are able to meet the specific needs of the population. ${ }^{75}$

Finally, liberal peace stands accused of being standardised and inflexible in practice. Faith in liberal peace and the key components of liberal peacebuilding - including democratisation, marketisation, establishing of rule of law and promoting human rights - results in a standardised, formulaic response to crises and peacebuilding. As Mac Ginty writes, "it becomes peace from IKEA; a flat-pack peace made from standardised components." ${ }^{, 76}$ A formulaic approach fails to properly consider the local context in which peacebuilding is to take place and the particular needs of the

\footnotetext{
${ }^{69}$ Snyder, From Voting to Violence: Democratization and Nationalist Conflict, 343.

${ }^{70}$ Richmond, "The Problem of Peace: Understanding the 'Liberal Peace'," 296.

71 Roland Paris, "Saving Liberal Peacebuilding," Review of International Studies 36, no. 2 (2010): 348.

${ }_{72}^{72}$ Mac Ginty, "Indigenous Peace-Making Versus the Liberal Peace," 140.

73 Ibid.: 144. See also Oliver P. Richmond, "Becoming Liberal, Unbecoming Liberalism: LiberalLocal Hybridity Via the Everyday as a Response to the Paradoxes of Liberal Peacebuilding," http://www.st-andrews.ac.uk/intrel/media/becoming_liberal.pdf (accessed 20 January 2011). 7

${ }^{74}$ Marina Ottaway, "Rebuilding State Institutions in Collapsed States," in State Failure, Collapse and Reconstruction, ed. Jennifer Milliken (Malden: Blackwell Publishing, 2003), 248.

${ }^{75}$ Ibid.

${ }^{76}$ Mac Ginty, "Indigenous Peace-Making Versus the Liberal Peace," 145.
} 
population. ${ }^{77}$ Critics hold reforms that do not respond to local needs will not survive once the international presence departs. ${ }^{78}$

In sum, this section has looked at some of the broader criticisms of liberal peace. The discourse has been accused of methods which are potentially destabilising including premature democratisation and economic reform which can exacerbate undercurrents of tension and lead directly to renewed conflict or undermine popular support for the peace process. Liberal peace has also been accused of being neo-colonial, culturally insensitive and too formulaic, which threaten the long-term sustainability of the introduced liberal structures. Such criticisms indicate liberal peace is not as unproblematic as the discourses suggests, and that the methods of liberal peace as well as the structures it reforms, affect the capacity for permanent peace. These issues are considered again later in Chapter II, when the specific failings in East Timor peacebuilding are reviewed in relation to general criticisms of the approach. The next chapter undertakes an immanent critique of liberal peace using the case study of East Timor.

\section{Chapter II: The East Timor Case Study}

This chapter undertakes an immanent critique of liberal peacebuilding in East Timor to assess the extent to which liberal peace meets its own standards of success and achieves its claim of fostering sustainable peace on the foundation of liberal structures. I argue that liberal peace fails to live up to its own standard of selfsustaining durable peace because the mechanisms of liberal peace and the emphasis on quick transitions lead to weak structures which have the appearance of liberal institutions but lack substance and domestic support. Furthermore, liberal peace provides a blueprint for peace which fails to consider the needs of the population or the specific context in which peace is to be set, weakening popular support for liberal structures and failing to create a peace dividend.

\footnotetext{
77 Eriksen, "The Liberal Peace Is Neither: Peacebuilding, State Building and the Reproduction of Conflict in the Democratic Republic of Congo," 660-61.

${ }^{78}$ Richmond and Franks, "Liberal Hubris? Virtual Peace in Cambodia," 30.
} 
The criteria for judging whether or not liberal peacebuilding can be deemed a success has been the subject of scholarly debate. As a minimal standard, the resumption of conflict is viewed as evidence of liberal peace failing, however, beyond that there is little consensus. ${ }^{79}$ There is debate over how much conflict constitutes a failure - whether the standard should be a certain number of casualties or if another international response is called. ${ }^{80}$ There is also debate over what timeframe should be used - if a mission can be deemed a success if there is order the moment foreign forces leave, ${ }^{81}$ or if it can only be judged a success if there has been no recurrence of violence within five, ten, or even 50 years. ${ }^{82}$ However, the absence of a return to violence may only amount to negative peace, ${ }^{83}$ while liberal peace has a broader definition of peace which includes the presence of elements as well as the absence of violence.

A more ambitious method of judging the success of liberal peace operations is the application of a maximalist standard or determining whether the root causes of conflict have been addressed and resolved. According to Call, there are general and particular root causes of conflict. ${ }^{84}$ General causes are social arrangements that can increase the risk of conflict, including inequality and poverty, regardless of the context in which they are present. Particular causes are those specific conditions that gave rise to a certain conflict; for example in Rwanda these would include ethnic tensions between the Hutu and Tutsi. Such a high standard, however, may be impractical for measuring the success of liberal peace operations as root causes are difficult to uncover and ameliorate, and even highly developed liberal states have risk factors for conflict. ${ }^{85}$

Given the limitations of both minimalist and maximalist standards, I have chosen to assess liberal peace by employing an immanent critique, or measuring the outcomes of peacebuilding against the stated claims of liberal peace. As discussed previously,

\footnotetext{
${ }^{79}$ Charles T. Call, "Knowing Peace When You See It: Setting Standards for Peacebuilding Success," Civil Wars 10, no. 2 (2008): 173.

${ }^{80}$ Ibid.: 178., and 181

${ }^{81}$ Paris, At War's End: Building Peace after Civil Conflict, 56.

${ }^{82}$ Call, "Knowing Peace When You See It: Setting Standards for Peacebuilding Success," 177.

${ }^{83}$ Charles T. Call and Elizabeth M. Cousens, "Ending Wars and Building Peace: International Responses to War Torn Societies," International Studies Perspectives 9, no. 1 (2008): 3.

${ }^{84}$ Call, "Knowing Peace When You See It: Setting Standards for Peacebuilding Success," 181-82.

${ }^{85}$ Ibid.: 182-83.
} 
liberal peace claims that the development of liberal structures offers a solution to conflict and will foster sustainable peace domestically and internationally. ${ }^{86}$ According to Paris, if this assertion is correct, liberal peacebuilding should not cause a return to violence, aggravate old tensions that led to conflict, or create new issues which are likely to cause renewed violence. ${ }^{87}$

East Timor was selected as the case study because it represents one of the most ambitious efforts by the UN and international agencies at liberal peace. For a period of almost three years, the UN assumed sovereignty of East Timor. During the UN's administration of East Timor, great emphasis was placed on the democratisation of politics, the marketisation of economics, the construction of rule of law, and, to a lesser degree, the development of human rights: the assumed pillars of sustainable peace. Given the extent of the UN mission, East Timor is an ideal case study for analysing liberal peace in greater depth.

My evaluation focuses on the liberal peacebuilding endeavours beginning October 1999 with the handover from the International Force for East Timor (INTERFET) to the UN administration and ends in 2002 with East Timorese independence and the declared successful conclusion of the UN administration. This marks the period in which the UN and other international organisations were particularly active in attempting to create or reform the key elements of a liberal society. This timeframe also matches the lifespan of the United Nations Transitional Administration in East Timor (UNTAET), the mission responsible for overseeing East Timor's transition to an independent liberal state. Consequently, the UNTAET mission is the central focus of this discussion; however, the World Bank's role in the planning of the East Timor economy is also considered. In evaluating the longer term success of these efforts at liberal peace, events since 2002 are considered, particularly the 2006 crisis.

The chapter is organised as follows: first, background to East Timor and the 1999 violence are briefly discussed in order to contextualise the UN peace mission. Then, an overview of the UNTAET operation is given in relation to the specific goals of liberal peace. Then, an immanent critique of liberal peace in East Timor is

${ }^{86}$ Paris, At War's End: Building Peace after Civil Conflict, 57.

${ }^{87}$ Ibid. 
undertaken which evaluates efforts in democratisation, marketisation, the establishment of rule of law, and the promotion of human rights against liberal peace's own standard of success. Finally, some of the weaknesses of liberal peacebuilding in East Timor are related to the general criticisms set out in Chapter I.

\section{Background and Indonesian Occupation}

This section will give a brief background into relevant East Timorese history. Of particular importance is the end of Portuguese colonisation and the political tension created by the decision to grant independence to East Timor. These conditions gave Indonesia the excuse to occupy East Timor while the international community largely turned a blind eye. The organisation of Indonesian rule systematically excluded the local population from participation in government, law, and senior professional positions, while attempting to suppress civil society. When a change in Indonesian government and mounting international pressure opened the door for East Timorese independence, the legacy of colonisation and occupation presented major challenges to the liberal peace operation that ensued.

East Timor was a Portuguese colony for centuries until political change in Portugal began the process of independence. The colonisation of Timor began in the $16^{\text {th }}$ century with the arrival of the Dutch and Portuguese who each claimed parts of the island. ${ }^{88}$ In 1893, the island was divided into two: the western side of the island came under the control of the Dutch while the eastern side remained Portuguese territory. With Indonesian independence from the Netherlands, western Timor became part of Indonesia while East Timor remained a Portuguese colony. ${ }^{89}$ Portuguese rule in East Timor was negligent and the colonists invested little in local infrastructure or development. $^{90}$

\footnotetext{
${ }^{88}$ Adam Schwarz, "East Timor: The Little Pebble That Could," in A Nation in Waiting: Indonesian in the 1990s (Boulder: Westview Press, 1994), 198. See also James J. Fox, "Tracing the Path, Recounting the Past: Historical Perspectives on Timor," in Out of the Ashes: Destruction and Reconstruction of East Timor, ed. James J. Fox and Dionisio Babo Soares (Hindmarsh: Crawford House Publishing, 2000), 12-13.

${ }^{89}$ Paul D. Elliott, "The East Timor Dispute," International and Comparative Law Quarterly 27, no. 01 (1978): 238.

${ }^{90}$ Schwarz, "East Timor: The Little Pebble That Could," 198.
} 
After centuries of colonial rule, political upheaval in Portugal prompted the decision to end Portuguese colonialism. The Carnation Revolution ushered in a new democratic government in Portugal which recognised its territories' right to selfdetermination and wanted to end Portugal's economic reliance on its colonies. ${ }^{91}$ Accordingly, in 1975 Portugal began preparations for East Timor's independence which was scheduled to come into effect in October 1978. To facilitate the transition to independence, the Portuguese introduced legislation in East Timor that allowed for the creation of an interim government in the lead up to and preparation for elections, due to be held in $1976 .{ }^{92}$ However, the route to independence was disrupted by fighting between political parties which escalated into civil war.

Generations of colonial rule had left a legacy in Timorese society: the population had no experience in democratic process and no institutions existed to mitigate political competition. Consequently, in 1975, political contestation descended into widespread violence. The initiation of decolonisation resulted in the emergence of three main political parties - Frente Revoluciondria Timor Leste (known as Fretilin), Unidio Democratica Timorense (UDT), and Associacao Popular Democratica de Timor (APODETI). These parties had conflicting policies towards independence which became a source of political tension and competition: Fretilin advocated for complete independence; UDT for an initial federation system with Portugal and gradual independence; while APODETI campaigned for East Timor to become part of Indonesia. ${ }^{93}$ On August $11^{\text {th }} 1975$, just weeks after the announcement of an interim government and the eventual end of Portuguese rule, UDT staged a coup. In response, Fretilin launched its own counter-coup and the country descended into civil war. ${ }^{94}$ Unable to control the violence, the Portuguese administration retreated, effectively deserting East Timor. ${ }^{95}$

Amidst the conflict, independence was declared by two political groups: Fretilin and a coalition of the other parties, and Indonesian troops landed in East Timor. Fretilin,

\footnotetext{
${ }^{91}$ Elliott, "The East Timor Dispute," 238. See also Sara Niner, "Martyrs, Heroes and Warriors: The Leadership of East Timor," in East Timor: Beyond Independence, ed. Damien Kingsbury and Michael Leach (Clayton: Monash University Press, 2007), 115-16.

${ }_{92}$ Elliott, "The East Timor Dispute," 239.

93 Ibid.

${ }^{94}$ Niner, "Martyrs, Heroes and Warriors: The Leadership of East Timor," 117.

${ }^{95}$ Elliott, "The East Timor Dispute," 239.
} 
militarily superior to the other parties, was able to physically defeat its opposition. On November $28^{\text {th }} 1975$, Fretilin announced East Timor's independence and sent key Fretilin members abroad to obtain international recognition and arms. ${ }^{96}$ Within days of their departure, Indonesian troops began their occupation of East Timor. Unable to return these key players spent the occupation in exile, and Fretilin became divided between those who stayed and fought, and those overseas who did not physically fight the Indonesians. ${ }^{97}$

Indonesia's occupation and forced annexation of East Timor was largely condoned or ignored by the international community ${ }^{98}$ with the exception of the UN. On December $12^{\text {th }} 1975$, just days after the Indonesian military invaded the small island, the UN General Assembly passed a resolution on the issue of Timor. The resolution reiterated the "inalienable right of all peoples to self-determination and independence", and condemned the use of force as contrary to the UN Charter. Further, the resolution specifically denounced the invasion and occupation, and called for Indonesian troops to withdraw immediately ${ }^{99}$ - calls Indonesia ignored.

During Indonesia's 25 year occupation, democracy, civil society, and development all suffered in East Timor. East Timorese were denied significant participation in professional and politics occupations. ${ }^{100}$ The Timorese were structurally discriminated against and systematically excluded from premier jobs that were reserved for Indonesians. ${ }^{101}$ Political dissent was not tolerated by the Indonesian army who employed a 'security approach' to any opposition. ${ }^{102}$ With no peaceful recourse to appeal to government, violence became a regular expression of dissatisfaction with Indonesian rule, to which the Indonesian army took a hard-line and often violent response to. An estimated 200,000 people were killed during the occupation $^{103}$ and there were widespread reports of human rights abuses by

\footnotetext{
${ }^{96}$ International Crisis Group, "Resolving Timor-Leste's Crisis," Asia Report 120 (2006): 2-3.

${ }^{97}$ Ibid.: 1.

${ }^{98}$ See Nicholas J. Wheeler and Tim Dunne, "East Timor and the New Humanitarian Interventionism," International Affairs 77, no. 4 (2001): 808-10.

${ }^{99}$ United Nations General Assembly, "Question of Timor," (GA Res. 3485 (XXX), UNGAOR, 30th Sess., Supp. 34, U.N. Doc. A/10034, pg 118, 1975). Para 1

${ }^{100}$ James Traub, "Inventing East Timor," Foreign Affairs 79, no. 4 (2000): 76.

101 Ibid.

102 Schwarz, "East Timor: The Little Pebble That Could," 197.

103 Traub, "Inventing East Timor," 76.
} 
Indonesian forces. ${ }^{104}$ The use of Timorese informants further divided the community and weakened civil society. ${ }^{105}$ Despite investing more than the Portuguese in education and infrastructure, poverty rates were still high, even in comparison to the rest of Indonesia. ${ }^{106}$ The Indonesian occupation, therefore, excluded local Timorese from the professional arena, stifled democratic process including civil society, encouraging dissatisfaction to be expressed through violence, and did not adequately address poverty in East Timor.

The Asia Financial Crisis precipitated the fall of the Indonesian president Suharto and instigated a change in East Timor policy. President Suharto's legitimacy rested largely on continued economic growth, so when the Indonesian economy collapsed, so too did support for the president. ${ }^{107}$ Suharto's successor, BJ Habibie had more immediate concerns of shoring up his presidency than of dealing with secessionist movements with the same vigour that Suharto exercised. ${ }^{108}$ Meanwhile, a number of different entities were applying pressure on Habibie's interim government to reexamine Indonesia's role in Timor. ${ }^{109}$ Among those pushing the Habibie administration was the International Monetary Fund (IMF) which had committed billions of dollars to Indonesia's economic recovery and wanted to reduce high military spending in East Timor. ${ }^{110}$ In May 1999, at the orchestration of the UN, President Habibie agreed to a 'popular consultation' in East Timor, to determine whether the people wanted special autonomy as part of Indonesia or independence. ${ }^{111}$ The consultation was scheduled for August and would been overseen by a UN mission (UNAMET), however, security was the responsibility of the Indonesians.

104 Joseph Nevins, "The Making Of "Ground Zero" In East Timor in 1999," Asian Survey 42, no. 4 (2002): 626.

${ }^{105}$ Schwarz, "East Timor: The Little Pebble That Could," 211.

106 Ibid., 206.

${ }^{107}$ Hal Hill and Takashi Shiraishi, "Indonesia after the Asian Crisis," Asian Economic Policy Review 2, no. 1 (2007): 124.

${ }_{108}$ Traub, "Inventing East Timor," 76.

${ }^{109}$ Wheeler and Dunne, "East Timor and the New Humanitarian Interventionism," 818.

${ }^{110}$ Richard Leaver, "Introduction: Australia, East Timor and Indonesia," The Pacific Review 14, no. 1 (2001): 5 .

111 Gorjao Paulo, "The Legacy and Lessons of the United Nations Transitional Administration in East Timor," Contemporary Southeast Asia 24, no. 2 (2002): 315. See also Ludovic Hood, "Security Sector Reform in East Timor, 1999-2004," International Peacekeeping 13, no. 1 (2006): 61. 
The 'popular consultation' was held on August $30^{\text {th }} 1999$ and showed massive support for independence. Despite intimidation and violence from TNI and proIndonesian sympathisers in the lead up to the vote, ${ }^{112}$ a staggering 98 per cent of East Timor's registered voters turned out to cast their vote. ${ }^{113}$ The result was overwhelmingly in favour of independence - around 80 per cent voted for independence, while approximately 20 per cent supported continued integration with Indonesia. $^{114}$

Immediately following the announcement of results, violence erupted which destroyed much of East Timor's physical infrastructure, caused thousands to flee the country, and displaced even more. The scorched earth campaign was carried out by pro-Indonesian militia and members of the Indonesian army (TNI), and despite claims to the contrary, there is evidence that high officials in the TNI knew of the intended campaign of violence or even helped plan and organise it. ${ }^{115}$ In a matter of mere weeks, an estimated 70 per cent of East Timor's physical infrastructure was destroyed. ${ }^{116}$ Hundreds, possibly thousands of people were killed as those carrying out the violence were instructed to kill anyone believed to be over the age of $15 .^{117}$ Moreover, three quarters of the population were displaced ${ }^{118}$ and approximately 250,000 fled the country. ${ }^{119}$ Among those that fled were the Indonesian professional class. $^{120}$

Under intense pressure, President Habibie agreed not only to a peacekeeping force but also announced East Timor's immediate secession from Indonesia. Faced with both moral and coercive pressure from the international community, Habibie consented to a peacekeeping force in East Timor. ${ }^{121}$ The International Force for East Timor (INTERFET) was an international coalition headed by Australia and

\footnotetext{
${ }^{112}$ Hood, "Security Sector Reform in East Timor, 1999-2004," 61.

113 Traub, "Inventing East Timor," 77.

${ }^{114}$ Ibid.

${ }^{115}$ Nevins, "The Making Of "Ground Zero" In East Timor in 1999," 624-25.

${ }^{116}$ Jarat Chopra, "The U.N's Kingdom of East Timor," Survival 42, no. 3 (2000): 27.

${ }^{117}$ Ibid.

118 Ibid.

119 Paulo, "The Legacy and Lessons of the United Nations Transitional Administration in East Timor," 315.

${ }^{120}$ Joel C Beauvais, "Benevolent Despotism: A Critique of U.N. State-Building in East Timor," New York University Journal of International Law and Politics 33, no. 4 (2000): 1104.

${ }^{121}$ Wheeler and Dunne, "East Timor and the New Humanitarian Interventionism," 818-21
} 
authorised by UN Security Council. The mission was mandated to end the violence in East Timor and reinstate order while offering support to UNAMET. ${ }^{122}$ The UN had planned that the popular consultation would be followed by a period of gradual independence. Instead, due to the level of violence, gradual separation from Indonesia was no longer a viable option and Indonesian occupying forces were immediately withdrawn, releasing East Timor without significant preparation. ${ }^{123}$ The UN responded by creating UNTAET to administer the territory in the interim while local capacity for independence was built.

In sum, this section has provided a brief introduction to East Timorese history. Centuries of colonial rule followed by a brutal Indonesian occupation left the population with little practical experience in political self-determination or democratic process. Indonesian oppression had also legitimised violence as a valid expression of social dissatisfaction. The violence of 1999 itself destroyed much of the nation's physical infrastructure and caused extensive displacement both internally and across international borders. Among those that fled were the predominantly Indonesian professional class leaving a skills and knowledge gap. This is the context in which UNTAET attempted to transplant its model of liberal peace. The next section provides an overview of UNTAET's mission while identifying the key characteristics of liberal peace in the mission.

\section{UN Attempts at Creating Liberal Peace in East Timor}

INTERFET was able to successfully end the violence in East Timor and in February 2000, the Australian led taskforce handed over authority to UN administrative officials. Where INTERFET had been concerned with ending the violence and establishing negative peace, UNTAET was now responsible for (re)building the state. The mission was clearly informed by a liberal peace framework and can be described as mixture of conservative and orthodox models. Evidence of the influence of liberal peace on the mission can be found in the emphasis given to politics, the economy, rule of law supported by the security sector, and to a lesser degree, human

122 Paulo, "The Legacy and Lessons of the United Nations Transitional Administration in East Timor," 315.

${ }^{123}$ Chopra, "Building State-Failure in East Timor," 983. 
rights. Each of these elements targeted for liberalisation is detailed below. The importance of the structure according to the liberal peace discourse precedes each brief overview of the UN's efforts to liberalise them.

UNTAET was authorised in October 1999 by the Security Council Resolution 1272. Headed by Sergio Vieira de Mello, the mandate of the UNTAET mission was broad: it was to be responsible for the temporary administration of the territory while also tasked with preparing East Timor for independence. ${ }^{124}$ In its role as administrator, UNTAET was given full sovereign power. This encompassed governance, legislature and the creation of new laws, and overall executive power. ${ }^{125}$ As Traub summarises, "the U.N. Transitional Administration for East Timor (UNTAET) is not just helping the new country's government-it is that government."126 Simultaneously, UNTAET was charged with overseeing East Timor's transition to independence. This second function of UNTAET required the administration to improve capacity for self-determination. ${ }^{127}$

The UNTAET mission in East Timor had the characteristics of both conservative and orthodox liberal peace models described in Chapter I. The UNTAET mission was an exercise in statebuilding making it in some respects a conservative peacebuilding operation. According to Chopra, the UN failures in Somalia and Afghanistan were still fresh in the organisation's memory, prompting the UN to take a top down approach to building a new state apparatus and cultivating peace in East Timor. However, in its quest to avoid repeating past mistakes, the UN overlooked the contribution local actors could make. ${ }^{128}$ Indeed, no East Timorese representatives were consulted during the UN's planning and research prior to the launch of UNTAET, and the UN even rejected modest requests from key political actor, Xanana Gusmao, for a Timorese Transitional Council which would have enabled the

\footnotetext{
${ }^{124}$ Beauvais, "Benevolent Despotism: A Critique of U.N. State-Building in East Timor," 1103.

125 Sue Downie, "U.N.T.A.E.T: State-Building and Peace-Building," in East Timor: Beyond Independence, ed. Damien Kingsbury and Michael Leach (Clayton: Monash University Press, 2007), 30 .

126 Traub, "Inventing East Timor," 74.

${ }^{127}$ United Nations Security Council, "The Situation in East Timor," (SC Res. 1272, UN SCOR, 54th sess, U.N. Doc. S/INF/55, pg 130 1999), 3. Section 2e

${ }^{128}$ Chopra, "Building State-Failure in East Timor," 981.
} 
local population to participate in the process. ${ }^{129}$ Consequently, when UNTAET was launched, there were no Timorese on the staff. ${ }^{130}$ A top down approach and a reliance on foreign support - both clearly evident in the UNTAET operation - are characteristics of a conservative model of liberal peace. ${ }^{131}$

While displaying some key traits of a conservative or statebuilding mission, UNTAET can also be described as an exercise in orthodox or democratic peacebuilding. Democratic peacebuilding focuses on the development of institutions that will support peace ${ }^{132}$ while having some concern for the local population. ${ }^{133}$ In accordance with the orthodox style of peacebuilding, the UN's missions in East Timor had some regard for local ownership and participation. The UNSC Resolution creating UNTAET declared it necessary for the mission:

to consult and cooperate closely with the East Timorese people in order to carry out its mandate effectively with a view to the development of local democratic institutions... and the transfer to these institutions of its administrative and public service functions. ${ }^{134}$

While UNTAET was criticised for not including Timorese early enough, later efforts at 'Timorisation' - including more local citizens on the staff - were made. ${ }^{135}$ Furthermore, the mission involved input from a range of agencies including international financial institutions ${ }^{136}$ and, to a limited degree, non-governmental organisations. $^{137}$

One of the first priorities of liberal peacebuilding in post-conflict societies is the democratisation of domestic politics. According to proponents of liberal peace, democracy and peace are interdependent. Domestically, democratic states have been found to have fewer instances of intrastate conflict than non-democratic states. ${ }^{138}$

129 Paulo, "The Legacy and Lessons of the United Nations Transitional Administration in East Timor," 316.

${ }^{130}$ Ibid.

${ }^{131}$ Richmond and Franks, "Liberal Hubris? Virtual Peace in Cambodia," 29-30.

132 Heathershaw, "Unpacking the Liberal Peace: The Dividing and Merging of Peacebuilding Discourses," 619.

${ }^{133}$ Richmond and Franks, "Liberal Peacebuilding in Timor Leste: The Emperor's New Clothes?," 188.

${ }^{134}$ United Nations Security Council, "The Situation in East Timor," 3. Section 8

135 Paulo, "The Legacy and Lessons of the United Nations Transitional Administration in East Timor," 319-20.

${ }^{136}$ Chopra, "The U.N's Kingdom of East Timor," 28.

137 Paulo, "The Legacy and Lessons of the United Nations Transitional Administration in East Timor," 319.

${ }^{138}$ Paris, At War's End: Building Peace after Civil Conflict, 42. 
This phenomenon is held to be due to the population's greater influence in politics and the containment of conflict to the political arena. Within functioning democracies local leaders are accountable to their citizens through regular elections which allow the public to show their satisfaction or dissatisfaction with political actors. In theory, the threat of elections and the chance of losing power to the opposition compel leaders to respond to the needs of the population. ${ }^{139}$ Additionally, democracy recognises different interests within society, and through the process of debate and negotiation resolves disputes peacefully through official means without parties resorting to violence. ${ }^{140}$ In societies recovering from conflict, it is the assumption of liberal peace that democratisation can redirect competition into politics and enable disputes to be resolved at the ballot box rather than through the taking up of arms. ${ }^{141}$

As well as a solution to internal conflict, democratisation is pursued in liberal peacebuilding as means of improving international peace. The emphasis on creating liberal democracies is driven by evidence, however critiqued, which shows liberal states are peaceful in their relations with other liberal democracies. ${ }^{142}$ Former US president Bill Clinton succinctly summarised this phenomenon with the phrase: "Democracies don't attack one another". ${ }^{143}$ The exact relationship between domestic government and international peace is still unclear, though there are a number of theories which attempt to explain the peace between liberal states. Among them is the theory promulgated by Kant which holds populations in a democracy have greater influence in the politics of liberal democracies, and are generally hesitant to pay the heavy social and financial costs of war, ${ }^{144}$ making conflict a potentially risky political move and, therefore, a decision democratic governments enter into more cautiously. ${ }^{145}$ Another theory puts forth the claim that conflict is irrational and as

\footnotetext{
139 Boutros Boutros-Ghali, "An Agenda for Development: Report of the Secretary-General," United Nations, http://www.un.org/Docs/SG/agdev.html (accessed online 10 December 2010). Para 128

${ }^{140}$ Ibid. Para 120. See also Paris, At War's End: Building Peace after Civil Conflict, 157.

${ }^{141}$ Paris, At War's End: Building Peace after Civil Conflict, 5.

142 Mandelbaum, The Ideas That Conquered the World: Peace Democracy, and Free Markets in the Twenty-First Century, 243.

143 Bill Clinton quoted in John M. Owen, "How Liberalism Produces Democratic Peace," International Security 19, no. 2 (1994): 87.

${ }^{144}$ Immanuel Kant, Perpetual Peace: A Philosophical Sketch (New York: Cosimo, 2005), 10.

${ }^{145}$ Owen, "How Liberalism Produces Democratic Peace," 89.
} 
rational bodies, liberal states are less inclined to engage in war. ${ }^{146}$ While criticisms and weaknesses of this assumed link between liberal states and international order have emerged, ${ }^{147}$ democratisation remains a primary focus of liberal peace praxis to improve both domestic and international peace prospects.

In accordance with liberal peace assumptions about the benefits to peace, UNTAET emphasised the importance of democratic elections. The organisation of national elections took almost two years to achieve. During this period, UNTAET was cautious not to work too closely with any political group or to bestow too much authority on a non-elected body. These precautions were to avoid inadvertently advancing one party's interests or power, which could affect the outcome of upcoming elections. ${ }^{148}$ Until national elections could take place, UNTAET was the sovereign power in East Timor, and more specifically, Sergio Vieira de Mello had executive authority. UNTAET did attempt to engage with local non-elected bodies such as the National Consultative Council (NCC), but these groups did not have the position or authority to greatly influence decisions. Consequently, key national decisions were the responsibility of UNTAET.

In August 2001, elections were carried out around the country for the Constituent Assembly. The results of the election gave Fretilin a significant majority in the assembly which was specifically charged with the drafting of the East Timorese constitution. The following April, presidential elections were held, which led to the election of Xanana Gusmao as the head of state. ${ }^{149}$ Following the presidential election, East Timor was officially declared an independent state, and the Constituent Assembly became the country's first parliament. ${ }^{150}$ The elections were peaceful, prompting the UN to announce their success and the conclusion of the UNTAET mission in East Timor. ${ }^{151}$ With its democratic government structure and

\footnotetext{
${ }^{146}$ Michael W. Doyle, "Kant, Liberal Legacies, and Foreign Affairs," Philosophy and Public Affairs 12, no. 3 (1983): 225.

${ }^{147}$ For a discussion see Christopher Layne, "Kant or Cant: The Myth of the Democratic Peace," International Security 19, no. 2 (1994), Steve Chan, "In Search of Democratic Peace: Problems and Promise," Mershon International Studies Review 41, no. 1 (1997).

${ }^{148}$ Beauvais, "Benevolent Despotism: A Critique of U.N. State-Building in East Timor," 1120.

${ }^{149}$ Chopra, "Building State-Failure in East Timor," 996.

${ }^{150}$ Downie, "U.N.T.A.E.T: State-Building and Peace-Building," 35.

${ }^{151}$ Chopra, "Building State-Failure in East Timor," 996.
} 
constitution, East Timor had the appearance and characteristics of a liberal democracy.

A second major focus of liberal peace in practice is the marketisation of local economic structures which is held to improve the national economy and reduce poverty. The freeing of markets entails encouraging the growth of the private sector and reducing government intervention in the economy. ${ }^{152}$ According to liberal principles, allowing the market to operate without interference increases efficiency, stimulating economic growth at a national and individual level. ${ }^{153}$ Economic reform and marketisation in theory serve peace domestically by reducing one of the general causes, or risk factors, of conflict: poverty. Furthermore, it is held that free markets and democracy are mutually reinforcing. ${ }^{154}$ Marketisation is also held to contribute to international peace, as trade between states can make the possibility of interstate conflict an expensive and unattractive option. ${ }^{155}$

In East Timor, the World Bank and UNTAET recommended economic reforms that were designed to improve growth. UNTAET and the World Bank were influenced by the assumption that a formal and open market economy based on private ownership was the ideal system for any society and that it would improve East Timor's prospects for peace. The World Bank recommended planting cash crops as a means of generating national economic growth through exports. ${ }^{156}$ Cash crops could also aid in formalising the economy, facilitate capitalism, and generate greater opportunities. ${ }^{157}$ The World Bank thus introduced agriculture projects that were directed at rehabilitating agriculture and promoting agriculture enterprise. ${ }^{158}$

\footnotetext{
${ }^{152}$ Paris, At War's End: Building Peace after Civil Conflict, 19.

153 Oliver P. Richmond, "Liberal Peace Transitions: A Rethink Is Urgent," Open Democracy http://www.opendemocracy.net/oliver-p-richmond/liberal-peace-transitions-rethink-is-urgent (accessed 23 November 2010).

${ }^{154}$ Mandelbaum, The Ideas That Conquered the World: Peace Democracy, and Free Markets in the Twenty-First Century, 11.

${ }^{155}$ Ibid., 266.

156 World Bank, "Timor-Leste: Economic and Social Development Brief," World Bank, http://go.worldbank.org/RZF7BL1H60 (accessed 10 January 2011). 7

${ }^{157}$ Richmond and Franks, "Liberal Peacebuilding in Timor Leste: The Emperor's New Clothes?," 197.

${ }^{158}$ For an overview of the projects, see: Trust Fund for East Timor (TFET), "Report of the Trustee Technical Appendix: Project Overviews," World Bank, http://siteresources.worldbank.org/INTTIMORLESTE/Resources/TFET-TechnicalAppendix_final.pdf (accessed 23 February 2011).
} 
The third key element of the liberal peace framework is the establishment of rule of law. Liberal peace advocates the transformation of the judicial system to create rule of law, which is defined as:

a principle of governance in which all persons, institutions and entities, public and private, including the State itself, are accountable to laws that are publicly promulgated, equally enforced and independently adjudicated, and which are consistent with international human rights norms and standards. ${ }^{159}$

The rule of law is fundamental in a market democracy. ${ }^{160}$ The courts and police service ensure democracy and the market function - protecting democratic rights and private property, and limiting the power of political leaders. ${ }^{161}$

In East Timor, the judicial system had been largely destroyed by the conflict. Physical structures were damaged and many legal professionals had fled. ${ }^{162}$ UNTAET began to completely reconstruct the legal system. The physical infrastructure was repaired and it was decided that Indonesian law would be remain in place, except legislation which clashed with international human rights. ${ }^{163}$ The next step for UNTAET was the recruitment and training of legal experts. In this task, UNTAET elected to hire local Timorese rather than rely on foreign candidates. To assist Timorese staff, many of whom had no practical experience, UNTAET offered training programmes and initiated a mentoring service with international legal professionals. ${ }^{164}$ In less than two years, UNTAET was able to get district courts in Dili, Baucau and Oecussi up and running, as well as the Court of Appeal in Dili. ${ }^{165}$

In conjunction with strengthening rule of law, the liberal peace framework recognises the importance of a security sector which provides necessary support to both the state and court system. Eriksen holds the security sector is a crucial element of statebuilding as he argues, in line with Weber, that one of the primary qualities of

159 United Nations Security Council, "Report of the Secretary-General: The Rule of Law and Transitional Justice in Conflict and Post-Conflict Societies," http://www.unrol.org/files/2004\%20report.pdf (accessed 09 January 2011). 4

${ }^{160}$ Paris, "Saving Liberal Peacebuilding," 342.

${ }^{161}$ Mandelbaum, The Ideas That Conquered the World: Peace Democracy, and Free Markets in the Twenty-First Century, 271.

${ }^{162}$ Hansjorg Strohmeyer, "Collapse and Reconstruction of a Judicial System: The United Nations Missions in Kosovo and East Timor," The American Journal of International Law 95, no. 1 (2001): 50 .

${ }^{163}$ Ibid.: 58 .

${ }^{164}$ Beauvais, "Benevolent Despotism: A Critique of U.N. State-Building in East Timor," 1153-54.

${ }^{165}$ Downie, "U.N.T.A.E.T: State-Building and Peace-Building," 36. 
a state is that it "successfully claims a monopoly of the means of violence". ${ }^{166} \mathrm{~A}$ functional security sector is imperative to ensuring no non-state parties attempt to challenge the state's monopoly. Moreover, a security sector is necessary to support the judiciary.

Accordingly, the creation of an East Timorese police force was an early and high priority for UNTAET. A local police force was central to the UN's mandate of preparing East Timor for independence. To achieve its goal of creating a police service, UNTAET included a Civilian Police (CivPol) contingent of 1,250 international experts. ${ }^{167}$ Between 1999 and 2002, CivPol participated in the recruitment and training of cadets for the East Timor National Police (PNTL). Significant attention and resources were given to recruiting sufficient numbers, though less attention was given to capacity building or ongoing training. ${ }^{168}$

While UNTAET was successful in creating a police service in a short period, the issue of creating a national armed force was more contentious in the UN, and therefore did not receive the same attention or support. A number of UN officials felt the organisation's assistance in the establishment of an East Timorese armed force would be in opposition to the UN Charter. It was argued that supporting the development of a national army which could potentially become a threat to peace, was counter to the spirit of the Charter and the function of the UN as an advocate for peace. ${ }^{169}$ As a result, UNTAET played a very limited role in the creation of the East Timorese defence force. ${ }^{170}$

Finally, human rights reform is also considered to be a necessary ingredient in liberal peacebuilding. Liberal peace discourse assumes that the introduction or the prioritisation of human rights can support other elements of liberal peace ${ }^{171}$ and

\footnotetext{
${ }^{166}$ Eriksen, "The Liberal Peace Is Neither: Peacebuilding, State Building and the Reproduction of Conflict in the Democratic Republic of Congo," 653.

${ }^{167}$ Hood, "Security Sector Reform in East Timor, 1999-2004," 65.

168 Ibid.

${ }^{169}$ Ibid.: 70 .

${ }^{170}$ Ibid.: 73 .

${ }^{171}$ Richmond, "The Problem of Peace: Understanding the 'Liberal Peace'," 299.
} 
reduce the causes of conflict. ${ }^{172} \mathrm{UN}$ and NGO led human rights reform in the past has included encouraging new leaders in post-conflict societies to commit to international human rights covenants ${ }^{173}$ and training sectors of society in human rights norms. ${ }^{174}$

In East Timor, UNTAET focused on democratic elections and emphasised that institutions must uphold international human rights norms. According to BoutrosGhali, democracy is a basic and vital human right. ${ }^{175}$ UNTAET thus worked towards democratic elections and took precautions not to unintentionally affect the outcome of such elections by favouring or working too closely with unelected political actors. ${ }^{176}$ Commitment to human rights in institutions is evident in the legal and police sectors. Sergio Vieira de Mello, the Transitional Administrator, publicly declared in 2000 that success in East Timor would be measured, in part, by the UNTAET's creation of "a credible system of justice in which fundamental human rights are respected." ${ }^{177}$ While UNTAET made the decision to keep Indonesian laws rather than create an entirely new set of laws in East Timor, these existing laws were purged of any articles that were deemed to be out of alignment with international human rights norms. ${ }^{178}$ In the security sector, human rights were included in CivPol led police training sessions for the newly created national police force. ${ }^{179}$

To summarise, the UNTAET mission was distinctly informed by liberal peace. It combined elements of conservative and orthodox peacebuilding models - seen in its top down approach to statebuilding, its late inclusion of Timorese, and the involvement of non-state actors. In its drive to create sustainable peace, UNTAET focused on the key components of liberal peace: democracy, free market economics, rule of law supported by the security sector, and, to a lesser degree, the promotion of

\footnotetext{
${ }^{172}$ Boutros-Ghali, An Agenda for Peace: Preventative Diplomacy, Peacemaking and Peace-Keeping, Report of the Secretary-General Pursuant to the Statement Adopted by the Summit Meeting of the Security Council on 31 January 1992. Para 5

${ }^{173}$ Richmond and Franks, "Liberal Hubris? Virtual Peace in Cambodia," 33.

${ }^{174}$ Paris, At War's End: Building Peace after Civil Conflict, 19.

175 Boutros-Ghali, "An Agenda for Development: Report of the Secretary-General." Para 120

${ }^{176}$ Beauvais, "Benevolent Despotism: A Critique of U.N. State-Building in East Timor," 1120.

${ }^{177}$ Quoted in Ibid.: 1111.

${ }^{178}$ Strohmeyer, "Collapse and Reconstruction of a Judicial System: The United Nations Missions in Kosovo and East Timor," 58.

179 Simonsen, "The Authoritarian Temptation in East Timor: Nationbuilding and the Need for Inclusive Governance," 589.
} 
human rights. The next section evaluates the successes and failures of each of these elements of liberal peace in East Timor by employing an immanent critique and utilising liberal peace's own parameters of success.

\section{Immanent Critique of Liberal Peace in East Timor}

The UN led peace operation followed a standardised model of liberal peacebuilding in East Timor which focused on four structures: democracy, free market economy, rule of law, and human rights. This section assesses each of these elements in turn using an immanent critique to evaluate whether liberal peacebuilding in practice lives up to its own standards and achieves its goals. In particular, this section is concerned with determining whether the institutions that were created, and the methods UNTAET employed to construct them, are likely to support long term peace in East Timor. One of the key benchmarks I use is the 2006 crisis in which protests by soldiers from the defence force escalated into violence. I argue that while UNTAET did attempt to repair or establish the key components of a liberal market democracy, many of these institutions lack substance and either contributed to the violence in 2006 , or failed to prevent it. UNTAET, therefore, successfully oversaw the transition to independence of a nation with all the markers of a liberal market democracy; however, whether these structures will support and sustain peace once foreign officials have left remains uncertain.

Liberal peace assumes sustainable peace rests on the foundations of a liberal society; therefore, its objective is the creation or liberalisation of these key structures in postconflict societies. Liberal peace makes a grand claim, but does peacebuilding in practice actually achieve this? Has the application of a liberal peace framework in contemporary peace operations indeed fostered lasting peace? If liberal peace is correct in its assumptions, Paris proposes that as a minimum peacebuilding should:

1) not cause fighting to resume; 2) not exacerbate pre-existing conditions that previously led to civil violence within the host state; 3) not create new conditions within the host state that are likely to spark a resurgence of fighting. ${ }^{180}$

\footnotetext{
${ }^{180}$ Paris, At War's End: Building Peace after Civil Conflict, 57.
} 
Using Paris' minimum standard as the basis for evaluating liberal peace in East Timor, UNTAET efforts at democratisation, marketisation, establishing rule of law and developing human rights are considered in greater depth. Particular attention is given to whether these structures meet this standard, how UNTAET's mechanisms for creating or reforming institutions affected their form, and what role, if any, these institutions played in mitigating or contributing to the 2006 crisis.

In brief, the 2006 crisis was initiated by the firing of almost 600 soldiers from the defence force who had gone on strike over perceived discrimination in the army against westerners (loromonu) by higher ranking easterners (lorosae). ${ }^{181}$ In April, the sacked soldiers held protests over their dismissal, which grew and transformed into political protests against the Fretilin government. ${ }^{182}$ Youth gangs contributed to the escalation of violence which the police service and defence force were unable to stop or contain. ${ }^{183}$ Violent skirmishes continued for the next five months, during which time, 30 people were killed ${ }^{184}$ and more than 100,000 displaced. ${ }^{185}$ Order was finally re-established with the arrival of another international peacekeeping force and the launch of new UN mission, UNMIT. ${ }^{186}$

\section{Democracy}

As detailed in the previous section, UNTAET organised and oversaw national elections for the Constituent Assembly followed by presidential elections. While these elections were declared to be free and fair and prompted UNTAET to announce the mission's success and conclusion, democracy is more than an election. ${ }^{187}$ Indeed, East Timor may have the infrastructure of a democracy and may experience peaceful elections, but the substance and durability of Timorese democracy is questioned. ${ }^{188}$ Elections in 2001 led the consolidation of Fretilin's power, while UNTAET's hierarchical and foreign-led operation did little to train

\footnotetext{
${ }^{181}$ Cynthia Brady and David G. Timberman, "The Crisis in Timor-Leste: Causes, Consequences and Options for Conflict Management and Mitigation," (USAID, 2006), 1.

${ }^{182}$ International Crisis Group, "Resolving Timor-Leste’s Crisis," 8.

${ }^{183}$ Ibid.: 9.

${ }^{184}$ Ibid.: ii.

${ }^{185}$ Ibid.: 1.

${ }^{186}$ Richmond and Franks, "Liberal Peacebuilding in Timor Leste: The Emperor's New Clothes?," 185.

${ }^{187}$ Paris, "Saving Liberal Peacebuilding," 361.

188 Simonsen, "The Authoritarian Temptation in East Timor: Nationbuilding and the Need for Inclusive Governance," 580.
} 
East Timorese in democratic process or encourage civil society. Political tensions, popular frustration with politics, and reliance on violence rather than political process were major factors in the 2006 crisis, undermining the claim of liberal peace that democracy inherently promotes peace.

The Constituent Assembly was democratically elected in 2001 and tasked with drafting East Timor's constitution. Fretilin won 55 out of the 88 seats in the assembly and used their majority to create a constitution which both advantaged Fretilin and undermined democracy. Known as the 'Fretilin Constitution', the legislation diminished the power and influence of the president and raised the position of prime minister. In doing so, the elected president, Xanana Gusmao, found his position was reduced to a figurehead despite receiving a significant majority in the presidential election. ${ }^{189}$ Furthermore, the constitution decreed the Constituent Assembly would transform itself into the national parliament without further elections. Fretilin was then able to dominate key positions, securing its power and influence. ${ }^{190}$ Mari Alkatiri, the Secretary General of the Fretilin Party was given the position of Prime Minister of the newly independent state. Alkatiri's leadership, however, bordered on authoritarianism, as Alkatiri undermined democratic processes and demanded all government decisions required his approval. ${ }^{191}$ Thus, elections prior to any serious political opposition to Fretilin and the biased constitution, Richmond and Franks argue, "allowed Fretilin to transform democracy into dictatorship as it consolidated its political power."192

The fostering of democracy in East Timor was also undermined by the contradictory mandate of UNTAET. UNTAET was charged with a number of tasks, including the administration of East Timor and preparing the territory for independence. The focus of the single mission was therefore split into short term and long term goals which UNTAET was unable to address equally. In its immediate focus on maintaining security and the day to day running of a post-conflict country, UNTAET relied on

\footnotetext{
${ }^{189}$ International Crisis Group, "Resolving Timor-Leste's Crisis," 4.

190 Simonsen, "The Authoritarian Temptation in East Timor: Nationbuilding and the Need for Inclusive Governance," 581.

${ }^{191}$ Richmond and Franks, "Liberal Peacebuilding in Timor Leste: The Emperor's New Clothes?," 193.

${ }^{192}$ Ibid.: 192.
} 
the "logic of peacekeeping"193 in which the UN had executive authority and the ability to make immediate decisions without the burden of consultation, thereby achieving quick results. ${ }^{194}$ In contrast, the mandate of overseeing East Timor's transition to independence demanded greater local inclusion and participation, institution and capacity building, and a more long term commitment. ${ }^{195}$ UNTAET, however, was planned by the Department of Peacekeeping Operations (DPKO) which had limited experience in governance. ${ }^{196}$ UNTAET was, thus, better organised to achieve short term peacekeeping goals than fostering self-government.

As a result of UNTAET's bias towards peacekeeping, the operation initially excluded the local population, undermining the long term goal of cultivating democracy. Despite UNTAET's objective of facilitating capacity building and civil society in preparation for democracy, no East Timorese were included in the early stages of its operation. This decision indicates the faith or hubris that liberalisation was universal and would take root in any context. ${ }^{197}$ The absence of local actors can further be explained by the UN's determination not to repeat past failures and by the mission's very personnel. ${ }^{198}$ Chopra contends that the operation, which granted power and control over the territory to a handful of officials, either appealed to personalities that were "intoxicated" by the idea of power, or "corrupted" others. ${ }^{199}$ Timorese were thus excluded in the planning and early stages of statebuilding.

Furthermore, the UNTAET mode of governance, typical of a peace mission, was hierarchical, centralised, and employed techniques that were in opposition to the objective of creating a self-sustaining Timorese democracy. Decentralisation is necessary for the effective management of a democratic state, however, when UNTAET arrived it recentralised governance. ${ }^{200}$ In the planning of the peacebuilding operation in East Timor, District Administrators were to have a degree of autonomy in decision making and financing throughout the territory. In practice, though,

\footnotetext{
${ }^{193}$ Beauvais, "Benevolent Despotism: A Critique of U.N. State-Building in East Timor," 1113.

${ }^{194}$ Ibid.: 1116.

195 Ibid.: 1113.

196 Astri Suhrke, "Peacekeepers as Nation-Builders: Dilemmas of the U.N in East Timor," International Peacekeeping 8, no. 4 (2001): 1.

${ }^{197}$ Richmond and Franks, "Liberal Hubris? Virtual Peace in Cambodia," 30.

${ }^{198}$ Chopra, "Building State-Failure in East Timor," 981.

199 Ibid.

${ }^{200}$ Ibid.: 986.
} 
UNTAET was again organised like a peacekeeping mission: it was highly centralised and District Administrators were given little independence or authority. ${ }^{201}$ Additionally, UNTAET disbanded the reconstruction committees established by UNAMET staff in the midst of the 1999 chaos and re-centralised authority. ${ }^{202}$ This prevented the UN mission from adequately responding to the pressing needs of specific regions and further excluded local voices.

Projects that did include Timorese were either undemocratic or unsupported by UNTAET. Limited efforts were made to include the population through the creation of the National Consultative Council (NCC) made up of both UN officials and Timorese actors, and its replacement the National Council (NC), which was entirely made up of East Timorese. However, members of both councils were selected by the Transitional Administrator, rather than elected, ${ }^{203}$ as it was believed elections would cause long delays in the establishment of a Timorese consultative body. ${ }^{204}$ The World Bank's Community Empowerment Project, meanwhile, was actively resisted by UNTAET. The project aimed to give the East Timorese experience with popular accountability and democracy through the establishment of democratically elected district councils and the disbursement of grants. The councils would have the responsibility of identifying and selecting community projects to fund. ${ }^{205}$ UNTAET rejected the proposal twice before bowing to pressure from the UN Secretary General. Despite rhetoric of democracy promotion and capacity building, UNTAET was reluctant to actually hand over control to the population. ${ }^{206}$

Democracy was also undermined by UNTAET's lack of accountability to the Timorese population which led to a loss of legitimacy as it placed the demands of donors over and above the needs of the people of East Timor. Part of the strength of an effective democracy is the power a population has to influence governance. A democratic government must consider the needs of its citizenry or else it will lose control to another party. UNTAET, in contrast, was in essence undemocratic. The

\footnotetext{
${ }^{201}$ Ibid.: 986-87.

202 Ibid.: 988.

203 Paulo, "The Legacy and Lessons of the United Nations Transitional Administration in East Timor," 317-19.

${ }^{204}$ Chopra, "Building State-Failure in East Timor," 992.

205 , "The U.N's Kingdom of East Timor," 30.

${ }^{206}$ Ibid.: 30-31.
} 
administration had not been elected and its staff was predominantly made up of foreigners, whose understanding of and commitment to national interests was questionable. ${ }^{207}$ In addition, the Transitional Administration and de Mello, its head, had no potential opposition, which allowed the administration to function without accountability to the local population. As Chopra argues:

The Transitional Administrator had always been more concerned with international, strategic-level politics, in the capital cities of the UN member states and donor governments. They were the real constituency, and the source of power and the determinant of his future, more than the Timorese people. ${ }^{208}$

Importantly, UNTAET assumed East Timor was 'terra nullius' and so did not attempt to engage with existing political structures. The UN's recruitment regulations required staff to be drawn from a range of states rather than enabling the organisation to hire purely on the basis of experience or knowledge. ${ }^{209}$ UNTAET staff lacked not only practice in governance, but also awareness of East Timorese culture and language. ${ }^{210}$ Consequently, it became taken for granted in UNTAET that East Timor had to be reconstructed entirely from scratch and that there were no existing domestic political structures once the Indonesian left. ${ }^{211}$

UNTAET thus approached democratisation in East Timor as though there was no competing local paradigm and that the population merely had to be versed in democracy for it to take root. ${ }^{212}$ This assumption was a mistake, as, in the words of Chopra, "there is never a [political] vacuum as long as there is a population."213 Throughout Portuguese and Indonesian control, traditional structures have continued to play an important role in Timorese society. Traditional society was arranged around Houses - or ancestry, physically represented by buildings. ${ }^{214}$ Political leaders could only originate from affluent Houses. When the Portuguese arrived, they

207 Paulo, "The Legacy and Lessons of the United Nations Transitional Administration in East Timor," 330.

${ }^{208}$ Chopra, "Building State-Failure in East Timor," 998.

${ }^{209}$ Beauvais, "Benevolent Despotism: A Critique of U.N. State-Building in East Timor," 1140.

${ }^{210}$ Ibid.: 1140-41.

${ }^{211}$ M. Anne Brown, "Security, Development and the Nation-Building Agenda - East Timor," Conflict, Security \& Development 9, no. 2 (2009): 149.

212 Tanja Hohe, "The Clash of Paradigms: International Administration and Local Political Legitimacy in East Timor," Contemporary Southeast Asia 24, no. 3 (2002): 570.

${ }^{213}$ Chopra, "Building State-Failure in East Timor," 981.

${ }^{214}$ Hohe, "The Clash of Paradigms: International Administration and Local Political Legitimacy in East Timor," 571. 
restructured Timorese society, stripping kings of their official authority and introducing village and sub-district chiefs. Despite these changes, kings maintained their influence and power either through transitioning from kings into chiefs or unofficially. ${ }^{215}$ During the Indonesian occupation, elections at the local level were introduced, however, descent continued to play an important role. Candidates were either drawn from royal Houses, or attempts were made to uncover links in a candidate's lineage to a royal House. Those with more tenuous links experienced less support from a population. ${ }^{216}$

Rather than engaging with local political structures, the UN attempted to transplant a democratic system, which clashed with Timorese traditions and consequently suffered from a lack of legitimacy. In response to growing criticism about the exclusion of the local population from the statebuilding exercise, UNTAET began to appoint Timorese staff in $2000 .^{217}$ District Field Officers, who acted as coordinators between a population and the government at a sub-district level, took on local counterparts that were to be trained to eventually replace the international officer. In the selection of local officers, however, emphasis was placed on education and work experience, often resulting in the appointment of younger individuals with no consideration of descent. This contrasted with traditional norms, which valued seniority and lineage, and undermined the legitimacy of officials in the eyes of the population. $^{218}$

The organisation of UNTAET and the means it employed to establish democracy in East Timor may have, in fact, weakened the long term prospects for democracy. Rather than focusing on training local actors to assume greater political control and authority in preparation for independence, UNTAET centralised the administration of East Timor and was initially resistant to including the population in statebuilding in any meaningful way. ${ }^{219}$ This alienated the Timorese from the very political processes they were due to inherit. Furthermore, democracy requires political opposition and a strong civil society, without which, there is no incentive for those in

\footnotetext{
215 Ibid.: 573-74.

${ }^{216}$ Ibid.: 577.

${ }^{217}$ Chopra, "The U.N's Kingdom of East Timor," 33.

218 Hohe, "The Clash of Paradigms: International Administration and Local Political Legitimacy in East Timor," 581.

${ }^{219}$ Beauvais, "Benevolent Despotism: A Critique of U.N. State-Building in East Timor," 1142-43.
} 
power to accommodate the needs or desires of a population. ${ }^{220}$ Where these are absent, a state may have the appearance of democracy but maintain illiberal practices. This represents a serious challenge to democracy - if the new leadership uses the rhetoric of democracy while continuing to practice violence or inequality, populations can become disillusioned with democracy. ${ }^{221}$ In East Timor, civil society is still developing and political processes which border on authoritarianism, risk the possibility of disillusionment.

In regards to Paris' criteria for the minimum standards of liberal peacebuilding, the process of democratisation itself did not immediately cause a return to violence with the exit of UNTAET; however, it did lead to conditions that fuelled the 2006 crisis, including Fretilin's consolidation of power. The 2006 crisis was initiated by the firing of almost 600 soldiers from the defence force who took to the streets in protests that soon escalated and led to scenes of violence. While beginning as a protest over perceived ethnic discrimination in the army and the mass firing, the protests quickly became sites for airing grievances with the state, including suspected official corruption and intimidation, and the lack of transparency in government. ${ }^{222}$ Fretilin's power hold and its style of governance, made possible by the actions of UNTAET, thus were among the causes of renewed fighting.

Furthermore, political divisions contributed to the crisis. During Indonesian occupation Fretilin became divided over resistance tactics and a split occurred in $1984 .^{223}$ Bitterness and rivalry from this split continued to effect politics even after independence, making it difficult for political figures such as Mari Alkatiri and Xanana Gusmao to work together. ${ }^{224}$ This division contributed to the 2006 crisis through the intentional and unintentional results of political intervention. The Interior Minister, the Defence Minister and the Defence Force Chief were all found to be responsible for arming civilians during the 2006 crisis to serve their causes. ${ }^{225}$ Meanwhile, President Xanana Gusmao met with the disgruntled soldiers which

\footnotetext{
${ }^{220}$ Paris, At War's End: Building Peace after Civil Conflict, 158.

${ }^{221}$ Ibid., 164.

${ }^{222}$ Damien Kingsbury and Michael Leach, "Introduction," in East Timor: Beyond Independence, ed. Damien Kingsbury and Michael Leach (Clayton: Monash University Press, 2007), 6.

${ }^{223}$ International Crisis Group, "Resolving Timor-Leste's Crisis," 3.

${ }^{224}$ Ibid.: 4.

${ }^{225}$ Kingsbury and Leach, "Introduction," 10.
} 
legitimised their complaints and their tactics. He further made public announcements which reinforced east/west divisions, ${ }^{226}$ and led to more violence against easterners. $^{227}$ For his part Prime Minister Alkatiri contributed to civil unrest by ignoring correct procedure and deploying the army to control protesting crowds. ${ }^{228}$ The army, however, did not have the experience or training for crowd control and began to fire on the crowd causing injury and death ${ }^{229}$ and further escalated the population's sense of panic, intensifying the crisis.

The use of violence to express political dissatisfaction and the involvement of politicians in the crisis indicate two connected issues. First, that UNTAET was more successful in creating veneer of democracy than in cultivating a robust democracy supported by institutions and strong civil society. Second, contrary to the assumption of liberal peace, the introduction of democracy in East Timor did not automatically transfer social conflicts to the political arena; rather violence remained a valid expression of dissatisfaction.

\section{Economics}

The second area targeted in liberal peacebuilding is the economy. Efforts in East Timor include promoting privatisation and cash crops, and international oversight of national funds. While these were directed at stabilising the economy, generating growth and preventing corruption or money mishandling, such measures did not create peace dividends for ordinary East Timorese. Indeed, despite support from the World Bank and revenue from natural maritime resources, the population has not benefitted greatly: unemployment, poverty and inequality are all high. One of the effects of poor economic development has been the emergence of youth gangs. In 2006, these gangs were involved in the riots that escalated into violence around the streets of Dili. While the economic reforms were not the cause of the 2006 crisis, the deterioration of quality of life contributed to the violence, further challenging the claim of liberal peace that marketisation will guard against violent conflict.

\footnotetext{
226 Ibid.

${ }^{227}$ International Crisis Group, "Resolving Timor-Leste's Crisis," 8.

${ }^{228}$ Ibid.: 9.

${ }^{229}$ Ibid.
} 
UNTAET was supported by the World Bank in its efforts to liberalise the East Timorese economy. Among the areas the World Bank recommended for reform was agriculture. The World Bank dismissed plans for a state-owned grain silo and abattoir, and public funding for research and development in the field of agriculture. $^{230}$ It argued that such resources would be too heavy a burden on the developing state, ${ }^{231}$ despite the World Bank's own estimates that 80 per cent of the population relies on agriculture, forestry, and fisheries for their survival, ${ }^{232}$ and the relief or peace dividend it would offer the population. The World Bank further advocated privatisation to improve productivity and to attract investment. ${ }^{233}$

The World Bank also argued for developing commercial crops in East Timor. According to the World Bank view, growing crops for international export benefits the economy and increases food security. ${ }^{234}$ In theory, trade creates cash reserves which can function as a buffer in a crisis, ${ }^{235}$ and a varied source of food supply, protecting populations against food shortages due to poor crop yields. ${ }^{236}$ Anderson, however, disputes this, arguing cash reserves typically do not withstand state emergencies and a heavy reliance on funds and international suppliers is in fact a threat to food security. ${ }^{237}$ Nevertheless, the World Bank began to implement its programme for agriculture reform in 2001, including creating three Agriculture Service Centres to assist in promoting cash crops and agriculture enterprise. ${ }^{238}$

Besides agriculture, East Timor also has reserves of petroleum and natural gas which have enormous potential for economic growth. However, the revenues from these natural resources have not been effectively channelled into improving the living conditions of ordinary East Timorese. While the maritime territory of East Timor is disputed, there are agreements in place with Australia in which East Timor is entitled

\footnotetext{
${ }^{230}$ Tim Anderson, "Food Security and Agriculture in the Australia-East Timor Relationship," in East Timor: Beyond Independence, ed. Damien Kingsbury and Michael Leach (Clayton: Monash University Press, 2007), 187-88.

${ }^{231}$ Ibid.

${ }^{232}$ World Bank, "Timor-Leste: Economic and Social Development Brief." 7

233 Ibid.

234 Ibid.

235 Anderson, "Food Security and Agriculture in the Australia-East Timor Relationship," 188.

${ }^{236}$ World Bank, "Timor-Leste: Economic and Social Development Brief." 7

${ }^{237}$ Anderson, "Food Security and Agriculture in the Australia-East Timor Relationship," 188.

238 Trust Fund for East Timor (TFET), "Report of the Trustee Technical Appendix: Project Overviews.", 4
} 
to a percentage of the revenues from the Joint Petroleum Development Area and Greater Sunrise fields. ${ }^{239}$ Concern that the abundance of wealth could be destabilising or create an incentive for government corruption, the international community organised foreign oversight of East Timor's petroleum wealth. Revenue from oil and gas is held in a fund managed by the US central bank. ${ }^{240}$ To ensure wealth from oil and gas does not disappear, the Banking and Payments Authority calculates the amount of income the East Timorese government can access annually without depleting the fund. ${ }^{241}$

Although the amount the East Timor government is able to access from its petroleum fund totals hundreds of millions of dollars annually, this has not been channelled into improving living conditions due to poor government capacity. Despite areas in need of development and significant revenue from gas and petroleum, the government has struggled to spend the proceeds. By the end of the third quarter for the 2006-2007 financial year, for example, the Timorese government had only spent US\$81 million of a US\$320 million budget. ${ }^{242}$ The World Bank attributes the failure to translate revenue into material improvements for the population to weak government ${ }^{243}-$ which lacks experience and expertise.

As a result of poor government and institutional capacity, marketisation and democratisation have not created a peace dividend in East Timor. When petroleum revenue is included in national income calculations per person, the country appears to have experienced significant economic growth. ${ }^{244}$ However, the majority of the Timorese population are not engaged in the oil sector of the economy and nonpetroleum GDP in fact declined between 2001 and $2005 .^{245}$ In 2006, it was estimated approximately 40 per cent of the population were living in poverty. ${ }^{246}$ Unemployment also remained high throughout UNTAET's mission and after its

\footnotetext{
${ }^{239}$ Kingsbury and Leach, "Introduction," 2.

${ }^{240}$ Richmond and Franks, "Liberal Peacebuilding in Timor Leste: The Emperor's New Clothes?," 196.

${ }^{241}$ World Bank, "Timor-Leste: Economic and Social Development Brief." 39

${ }^{242}$ Ibid. 2

243 Ibid.

${ }^{244}$ Ibid. 13

245 Brady and Timberman, "The Crisis in Timor-Leste: Causes, Consequences and Options for Conflict Management and Mitigation," 11.

${ }^{246}$ Ibid.
} 
conclusion. ${ }^{247}$ Furthermore, the weak Timorese government has not effectively introduced welfare or development programmes to address chronic poverty and unemployment. ${ }^{248}$ Continued poverty and unemployment increased disappointment and frustration among the population over unrealised expectations of independence. $^{249}$

High unemployment among the youth also precipitated the development of youth gangs. Youths in East Timor are particularly affected by unemployment. High fertility rates and poor economic performance limits the job market's capacity to absorb new entrants. Around 34 per cent of the population is aged between 12 and 29 years, ${ }^{250}$ which leads to around 15-20,000 new young people joining the labour force each year, while a mere 400 formal jobs are created annually. ${ }^{251}$ Youths also face language barriers. Due to the nascent private sector, most job prospects are with the government, where Portuguese is the official language. However, prior to 1999, children were educated in Indonesian and many youths do not speak Portuguese, posing a barrier to official positions. ${ }^{252}$ Many youths have migrated to urban centres in search of work, ${ }^{253}$ where youth unemployment is estimated to be around 44 per cent, approximately double the rate of non-youths. ${ }^{254}$ Without jobs or studies to preoccupy them, the youths began to form gangs. In 2006, these youth gangs, while not responsible for initiating the protests or violence, quickly became the main participants in the crisis. ${ }^{255}$

The 2006 protests by dismissed soldiers developed into demonstrations of public frustration over ongoing unemployment and poverty. By the fifth day of protests, the former soldiers were joined by members of the public and became demonstrations

\footnotetext{
${ }^{247}$ Chopra, "The U.N's Kingdom of East Timor," 34. Richmond and Franks, "Liberal Peacebuilding in Timor Leste: The Emperor's New Clothes?," 189.

${ }^{248}$ Richmond and Franks, "Liberal Peacebuilding in Timor Leste: The Emperor's New Clothes?," 196-97.

${ }^{249}$ Brady and Timberman, "The Crisis in Timor-Leste: Causes, Consequences and Options for Conflict Management and Mitigation," 11.

${ }^{250}$ Markus Kostner and Samuel Clark, "Timor-Leste's Youth in Crisis: Situational Analysis and Policy Options," World Bank, http://go.worldbank.org/8MR7LHVIX0 (accessed 17 January 2011). 7

${ }^{251}$ World Bank, "Timor-Leste: Economic and Social Development Brief." 2

${ }^{252}$ Ann Wigglesworth, "Young People in Rural Development," in East Timor: Beyond Independence, ed. Damien Kingsbury and Michael Leach (Clayton: Monash University Press, 2007), 52.

${ }^{253}$ Kostner and Clark, "Timor-Leste's Youth in Crisis: Situational Analysis and Policy Options." 10

${ }^{254}$ Richmond and Franks, "Liberal Peacebuilding in Timor Leste: The Emperor's New Clothes?," 189.

${ }^{255}$ Kostner and Clark, "Timor-Leste's Youth in Crisis: Situational Analysis and Policy Options." 7
} 
against the Alkatiri government. ${ }^{256}$ Among the population's economic grievances were continued high rates of poverty and unemployment. ${ }^{257}$ Also participating in the protests were hundreds of youths, many of them linked to gangs. ${ }^{258}$ As the protests turned into riots, the youths were very active in the crisis - engaging in looting and precipitating the dissolution of law and order. ${ }^{259}$

International efforts at liberalisation and marketisation in East Timor were more concerned with strengthening the nation's economy than improving conditions for ordinary people. Reforms should be lauded for their long term scope and objective of limiting corruption and government mismanagement, while insuring continued petroleum revenues. However, the economic reforms implemented during UNTAET's liberal peacebuilding mission failed to address the pressing situation for the significant portion of Timorese citizens living below the poverty line and struggling to find employment. UNTAET further under-estimated the importance of capable institutions in maximising and channelling economic growth to needed areas.

In sum, economic reforms in East Timor failed to meaningfully address poverty or unemployment, issues that contributed to the 2006 crisis, and so do not meet the minimum standard of liberal peace. International involvement in East Timor's economy focused on creating the infrastructure of a market economy, advocating cash crops and privatisation, and ensuring state revenue did not fall prey to corruption. While these endeavours were directed at the long term security of East Timor's economy, there was little consideration for ensuring institutional capacity in managing the economy, or creating peace dividends for ordinary citizens. Consequently, unemployment and poverty continued to affect a significant portion of the population, while quality of life declined. These conditions fuelled both disillusionment and anger among the general public, and gave rise to youth gangs. In the 2006 crisis, protests escalated because they became a "lightning rod" for legitimate grievances over the economy, ${ }^{260}$ and youths became the main participants

\footnotetext{
${ }^{256}$ International Crisis Group, "Resolving Timor-Leste's Crisis," 8.

${ }^{257}$ Kingsbury and Leach, "Introduction," 6.

${ }^{258}$ International Crisis Group, "Resolving Timor-Leste's Crisis," 8.

${ }^{259}$ Kostner and Clark, "Timor-Leste's Youth in Crisis: Situational Analysis and Policy Options." 7

${ }^{260}$ Kingsbury and Leach, "Introduction," 6.
} 
in the crisis. ${ }^{261}$ While economic reforms did not instigate the crisis, it is evident that the conditions created by such reforms were a contributing factor in the continuation and escalation of the conflict. Thus, economic reforms in East Timor do not meet the minimum standard of liberal peace because they failed to prevent a resurgence of violence.

\section{Rule of law and Human Rights}

The third and fourth areas of liberal peacebuilding in East Timor were the establishment of rule of law supported by the security sector, and human rights. UNTAET performed well in creating a functioning legal system, however, the lack of resources threaten its ability to support democracy and the market economy. More concerning is that the mechanisms and priorities employed by UNTAET in its creation of a police service undermine the importance of human rights, and limit the police institution's capacity to operate independently and impartially. UNTAET also failed in its obligation as administrator to ensure the defence force had adequate legal and institutional foundations, leading to similar problems with capacity and management. These weaknesses in the security sector became major factors in the 2006 crisis, once again revealing liberal peace practice often fails to meet the minimum standard of liberal peace theory.

The UNTAET approach to the judicial system has been lauded for emphasising local participation and attempting to build capacity. Unlike its approach to staffing in other departments, UNTAET recruited East Timorese to fill roles in the judiciary, rather than relying heavily on international actors. Those hired were given initial training, then ongoing support from international experts. ${ }^{262}$ According to Beauvais the hiring and support of local actors increased the courts' legitimacy in the eyes of the East Timorese public and signified a break from the past in which the judiciary was tool of the state and a mechanism for Indonesian suppression. ${ }^{263}$

Despite such achievements in the judiciary, the court system faces problems with resourcing and cultural appropriateness, which limit its ability to effectively

\footnotetext{
${ }^{261}$ Kostner and Clark, "Timor-Leste's Youth in Crisis: Situational Analysis and Policy Options." 7

${ }^{262}$ Beauvais, "Benevolent Despotism: A Critique of U.N. State-Building in East Timor," 1153-54.

${ }^{263}$ Ibid.: 1158.
} 
administer justice and uphold human rights, and potentially undermine its durability. UNTAET effectively rebuilt the legal system, but failed to adequately resource it. The court's lack of funds has led to significant delays in trials and even the release of a number of accused perpetrators. ${ }^{264}$ Furthermore, UNTAET focused on the formal system based on international best practices rather than incorporating or engaging with traditional forms of justice. ${ }^{265}$ Transplanting foreign models may satisfy donors' expectations of a justice system, but it also risks creating structures that are less culturally appropriate for their specific setting. ${ }^{266}$ In East Timor, an Asia Foundation survey found many citizens had concerns over the cost, fairness, and accessibility of the formal justice system. ${ }^{267}$

While the legal system has ongoing problems with resourcing and cultural appropriateness, overall it enjoys a high level of legitimacy and support from the local population. UNTAET's efforts at developing a national police force, however, did not have the same emphasis on capacity building or long term vision, and were less successful. In particular, UNTAET's failure to significantly consult with the population in its recruitment of police cadets and its short term approach to the task led to serious flaws. UNTAET employed western processes and standards to select individuals for the force, rather than working with the local population to recruit cadets with the traits and skills that would most benefit the community. For example, Hood argues those with knowledge of the English language were favoured, despite less than one percent of East Timorese speaking the language. ${ }^{268}$

Additionally, UNTAET focused on the quick recruitment and training of sufficient numbers of cadets rather than on the quality of applicants. ${ }^{269}$ Consequently, the East Timor police force was soon established, but in its haste UNTAET rehired several former members of the Indonesian police force. Though vetted, any individual that had served on the Indonesian police force was nevertheless part of the enforcement

\footnotetext{
${ }^{264}$ Ibid.: 1155.

${ }^{265}$ Cynthia Burton, "Security Sector Reform: Current Issues and Future Challenges," in East Timor: Beyond Independence, ed. Damien Kingsbury and Michael Leach (Clayton: Monash University Press, 2007), 107.

266 Ibid., 108.

${ }^{267}$ Ibid., 107.

${ }^{268}$ Hood, "Security Sector Reform in East Timor, 1999-2004," 64.

${ }^{269}$ Ibid.: 65.
} 
arm of the Indonesian regime and therefore implicated in the human rights abuses conducted during the occupation. Their experience and previous work ethic were further at odds with the new approach the UN wanted the police force to take. ${ }^{270}$ Regardless of this risk, former police professionals were not only rehired for the new national police service, but many were also promoted to positions within the higher echelons of the police force based on their previous practical experience. By 2006, former members of the Indonesian police force made up only a small portion of the new service, yet were over-represented at the elite level. ${ }^{271}$

In its staffing and training choices, UNTAET prioritised speed over East Timor's long term needs, compromising the goal of promoting human rights and capacity building. The reliance on former members of the Indonesian police force and the promotion of these individuals to high ranking offices threatens the UN's goal of developing and promoting human rights in East Timor. Granting former participants in the apparatus of Indonesian occupation key positions in the new security sector undermines the police force's commitment to upholding human rights and threatens to allow complacency towards human rights abuse to become systemic. Furthermore, UNTAET put the need of creating a police force ahead of the long term need for East Timor to have a self-sufficient, independent force. Accordingly, cadets were trained quickly but few efforts were made to stimulate capacity building. ${ }^{272}$ Hood accuses UNTAET of poor planning and inadequate staffing. He notes that of the 1,250 CivPol positions, only two were dedicated to the development of a police force institution. Meanwhile planning by the UN's Civilian Police Division in New York focused on achieving police quotas rather than on "developing a viable institution with adequate management systems and planning capabilities." 273

UNTAET had a less hands-on approach to the development of an East Timorese defence force. ${ }^{274}$ Indeed, UNTAET was reluctant to assist in the creation of a defence force and initially dismissive of the rebel forces. As the territorial

\footnotetext{
270 Simonsen, "The Authoritarian Temptation in East Timor: Nationbuilding and the Need for Inclusive Governance," 589.

${ }^{271}$ Ibid.

272 Ian Martin and Alexander Mayer-Rieckh, "The United Nations and East Timor: From SelfDetermination to State-Building," International Peacekeeping 12, no. 1 (2005): 135.

${ }^{273}$ Hood, "Security Sector Reform in East Timor, 1999-2004," 65.

${ }^{274}$ International Crisis Group, "Timor-Leste: Security Sector Reform," Asia Report 143 (2008): 12.
} 
administrator, UNTAET had the responsibility of ensuring the security sector was supported by institutional and legislative foundations. ${ }^{275}$ However, the army, like the police service lacked institutional capacity from its inception. The army further struggled with internal divisions and competition with the police force, issues which became factors in the 2006 crisis.

UNTAET failed to recognise the service of Falintil, the rebel force, or its cultural significance. Falintil, or Forças Armadas de Libertação Nacional de Timor Leste (Armed Forces for the National Liberation of East Timor), was formed in 1975 and originally functioned as the military component of Fretilin. In 1987, as a result of the Fretilin split, Falintil separated from Fretilin to become a politically neutral army. ${ }^{276}$ During the 1999 crisis, Falintil displayed remarkable self-discipline and did not engage with the Indonesian army, in the knowledge that escalating violence could risk international intervention. ${ }^{277}$ Yet despite Falintil's long-term involvement in the resistance and its support of the UN mission, UNTAET considered it to be an illegal armed force and attempted to disarm the fighters. ${ }^{278}$ UNTAET, Paulo writes:

did not allow Falintil to participate together with its own military component in the security patrols around the territory (even though INTERFET did benefit from their local intelligence, local knowledge, and general advice in the earlier phase). Despite Falintil's past role and historic legitimacy, it was placed under cantonment and conveniently sidelined... 279

When the Timorese decided to create a domestic defence force, UNTAET was reluctant to become involved due to a perceived conflict of interest. Nevertheless, UNTAET, as East Timor's administrator, was still responsible for ensuring the defence force had an institutional framework and capacity to operate effectively. However, UNTAET failed in this duty. The Timorese relied on support from bilateral donors in the development of the defence force, rather than the UN. ${ }^{280}$ Even though it was not managing the development of the army, as administrator,

\footnotetext{
275 Ibid.: 5 .

276 ,

277 Ibid.: 5 .

278 Simonsen, "The Authoritarian Temptation in East Timor: Nationbuilding and the Need for Inclusive Governance," 588.

279 Paulo, "The Legacy and Lessons of the United Nations Transitional Administration in East Timor," 317.

${ }^{280}$ International Crisis Group, "Timor-Leste: Security Sector Reform," 12.
} 
UNTAET should have set the foundations of the defence force "in the form of basic legislative and planning documents, administrative support and mechanisms for democratic control, or to develop a national consensus on security policies and structures through consultations." ${ }^{281}$ No such initiatives were implemented by UNTAET, ${ }^{282}$ and the defence force struggled with institutional weaknesses and internal divisions in the lead up to the crisis.

In 2006, army and police institutional weaknesses were directly responsible for the emergence and escalation of the 2006 crisis. Divisions with the defence force between easterners and westerners developed but institutional weaknesses led to the mismanagement of the tension. Perceived discrimination of westerners by easterners prompted soldiers from the west to petition political leaders and later go on strike. ${ }^{283}$ When army officials responded by dismissing those on strike, the former soldiers began protesting. As the protests grew, Prime Minister Alkatiri called on the army to restore order. The perception that those still in the army were pro-easterners and those protesting were pro-westerners fuelled ethnic divisions. ${ }^{284}$

Competition between the army and police further escalated the crisis. From 2002, the police force was increasingly politicised as Rogerio Lobato, a long-standing member of Fretilin, used his position as the Interior Minister, to recruit new police staff based on their loyalty to him. ${ }^{285}$ Without clear delineation of the intended roles of the army and police, the two security sectors competed and clashed over common tasks. Because the police units had access to better resources than the army and were paid more, tensions between the police and army grew. ${ }^{286}$ Allegations of human rights abuses by police officers as well as corruption began to surface, further intensifying the tension between the police and army. ${ }^{287}$ As the protests grew, police and army troops clashed, and in one incident, soldiers killed ten unarmed police officers. ${ }^{288}$

\footnotetext{
${ }^{281}$ Ibid.: 5 .

282 Ibid.

${ }^{283}$ Kingsbury and Leach, "Introduction," 5-6.

${ }^{284}$ International Crisis Group, "Resolving Timor-Leste's Crisis," 9.

285 Ibid.: 5 .

${ }^{286}$ Ibid.: 6 .

${ }^{287}$ Kingsbury and Leach, "Introduction," 5. See also Burton, "Security Sector Reform: Current Issues and Future Challenges," 105.

${ }^{288}$ Kingsbury and Leach, "Introduction," 22.
} 
UNTAET's approach to security, therefore, was underwhelming and failed to meet the standards of liberal peace. Once again, peacebuilding efforts in East Timor concentrated more on creating the framework of liberal rule of law with the expectation that this would naturally protect against renewed conflict once UNTAET left; however, these institutions lacked substance and quickly degenerated, contributing to the 2006 crisis. UNTAET's emphasis on speed in developing the national police force sacrificed capacity building, undermining the potential strength and robustness of the institution, as well as weakening the UN's message of human rights. Moreover, in its reluctance to lead the development of a defence force lead, UNTAET failed in its duty as administrator to ensure the army was supported by legislation and clear planning. Consequently, the police and defence force suffered from institutional weaknesses leading to competition between them, politicisation of the police, and poorly managed factions within the army. These weaknesses caused the initial crisis and escalated the violence of the crisis. The police and defence services have since been dissolved and targeted for reform by the latest UN mission and the East Timorese government in a bid to improve these services. ${ }^{289}$

Thus, liberal peacebuilding efforts that targeted rule of law and human rights were not effective in fostering long-lasting peace. UNTAET's efforts, particularly in relation to establishing rule of law supported by the security sector, aggravated social tensions and failed to provide the police and army with essential institutional support. Despite liberal peace claims about the potential for rule of law and human rights to engender durable peace, in East Timor, human rights were subverted for convenience and speed, and the security sector was directly responsible for the initial outbreak of protests and contributed to the violence.

\section{Liberal Peace Weaknesses in East Timor}

The East Timor case study illustrates a number of the criticisms of liberal peace set out in Chapter I. In particular, the poor outcome of liberal peacebuilding in East Timor can be attributed to its formulaic top-down approach, its disregard for local needs, and its failure to deliver peace dividends. These failings resulted in weak

${ }^{289}$ International Crisis Group, "Timor-Leste: Security Sector Reform," 1. 
institutions with insufficient domestic support and limited the sustainability of peace, and the state, without international support.

First, the methods employed by UNTAET illustrate the potential for liberal peace to be hierarchical and formulaic in practice. Liberal peace relies on external intervention with limited dialogue with the affected population. ${ }^{290}$ In East Timor, the UN failed to include any Timorese in the initial planning of the mission. Timorese were also missing from UNTAET until domestic pressure forced the project to include more local staff. ${ }^{291}$ The hierarchical organisation of UNTAET limited the involvement of the local population in constructing the new state, and limited the training of Timorese officials prior to independence. Furthermore, the singular objective of developing a liberal state, as imagined by the interveners and without any input from the population, creates a power dynamic in which the "the relationship between donors and recipients becomes one between subject and object, where all key decisions are made by one party and applied to the other."292

Second, the case study also illustrates the lack of consideration for local culture in the liberal peacebuilding agenda. Liberal peace believes in the universality of liberalism and assumes once liberal structures are in place they will be operational and self-sustaining. Therefore, peacebuilding introduces reforms without much consideration for whether or not such changes are culturally appropriate. ${ }^{293}$ However, East Timor illustrates that there are always existing political structures and practices which may clash with liberal ideas and need to be considered. Furthermore, unless introduced or liberalised structures are culturally relevant, they risk limited popular support and possible collapse.

Third, liberal peace fails to deliver peace dividends. Liberal peace follows a blueprint of reforms and liberalisation which do not adequately consider the effects

\footnotetext{
${ }^{290}$ Eriksen, "The Liberal Peace Is Neither: Peacebuilding, State Building and the Reproduction of Conflict in the Democratic Republic of Congo," 663.

291 Paulo, "The Legacy and Lessons of the United Nations Transitional Administration in East Timor," 319.

292 Eriksen, "The Liberal Peace Is Neither: Peacebuilding, State Building and the Reproduction of Conflict in the Democratic Republic of Congo," 663.

${ }^{293}$ Hohe, "The Clash of Paradigms: International Administration and Local Political Legitimacy in East Timor," 570.
} 
on the population. In East Timor, much of the population was experiencing chronic poverty and unemployment. Rather than engaging with the population, hearing their needs, and cultivating conditions that would address these issues and improve the everyday lives of ordinary Timorese, the UNTAET mission focused on creating the infrastructure of a liberal state, ${ }^{294}$ in the assumption that order and development will naturally follow liberalisation. ${ }^{295}$ Instead, poverty and unemployment continued, fuelling disillusionment with independence and contributing to the resurgence of violence in $2006 .{ }^{296}$ East Timor poignantly demonstrates the criticism that if peace is not accompanied by improvements in conditions, it will receive less popular support.

\section{Chapter Summary}

In sum, evaluating liberal peace in East Timor against the discourse's own minimum standard of success has shown that liberal peacebuilding in this case was not successful in fostering sustainable peace. Significant international attention was given to the four critical areas of democratisation, marketisation, rule of law and human rights; yet despite creation or reformation of the supposed foundations of a liberal society and sustainable peace, East Timor descended into violence in 2006 which only ended with the arrival of another international peacekeeping force and the launch of a new UN mission. ${ }^{297}$ Indeed, many of the institutions reformed or liberalised by international organisations were weak, lacked domestic support, and contributed to conditions of disillusionment and anger which were expressed through violence in 2006. Thus, the liberal peace operation in East Timor cannot be judged a success. Moreover, this case study illustrates that a number of criticisms of liberal peace methods are legitimate. In the next chapter I argue despite these weaknesses liberal peace still has merit and is a legitimate response to conflict. Liberal peace should therefore be reformed rather than discarded.

\footnotetext{
${ }^{294}$ Richmond and Franks, "Liberal Peacebuilding in Timor Leste: The Emperor's New Clothes?," 197. 295 _

296 Brady and Timberman, "The Crisis in Timor-Leste: Causes, Consequences and Options for Conflict Management and Mitigation," 11.

${ }^{297}$ Richmond and Franks, "Liberal Peacebuilding in Timor Leste: The Emperor's New Clothes?," 185.
} 


\section{Chapter III: Lessons from East Timor}

The previous chapter employed liberal peace's own standards to evaluate its successes and failures in East Timor. Despite being the dominant discourse or framework informing peace missions, the East Timor case study indicates liberal peacebuilding has the potential to contribute to renewed conflict or at least fail to prevent it. Liberal peacebuilding in practice, therefore, does not foster the peace envisioned in its ideology and is not a "silver bullet" for conflict and unrest. ${ }^{298}$ This assessment puts into doubt liberal peace's claims that liberalisation is the basis for sustainable peace, and justifies renewed thinking about the application of liberal peace.

This chapter argues that despite significant flaws in its methodology, there is still potential for liberal peace to mitigate social unrest. Therefore, I do not advocate the abandonment of a liberal approach to peacebuilding; rather I follow the lead of Paris in calling for reform from within liberal peace discourse. ${ }^{299}$ Three recommendations are put forth to strengthen and improve liberal peacebuilding: efforts at peace should move away from the standardised approach; there should be greater involvement from the local population and more consideration for their needs; and greater support should be given for capacity building and institutions.

Despite weaknesses in the methods of liberal peace, alternatives including giving war a chance, long term trusteeships, and relying on local leaders, are not viable, and thus liberal peace should not be abandoned. According to Paris, forgoing intervention to give war a chance may result in military victory and a more durable settlement; however, it also risks an increased humanitarian crisis, and a more prolonged conflict that may spill over into neighbouring states. ${ }^{300}$ Another alternative to liberal peace could be an illiberal, indefinite trusteeship of conflicting societies by international agencies, although such an arrangement would be even more neo-colonial and hierarchical than liberal peace and likely lack the support of

\footnotetext{
${ }^{298}$ Richmond, "Liberal Peace Transitions: A Rethink Is Urgent."

299 See Paris, "Saving Liberal Peacebuilding." See also —-, At War's End: Building Peace after Civil Conflict, Chapter 10.

${ }^{300}$ Paris, At War's End: Building Peace after Civil Conflict, 357.
} 
the population. Even the reliance on local leaders rather than democratic elections is problematic as these individuals could work to increase and consolidate their own power base through potentially violent means. ${ }^{301}$

Considering the shortcomings of alternatives and the potential benefit of stable liberal states locally and globally, the liberal peace approach does have merit and is therefore deserving of reform. As previously detailed, evidence indicates that mature liberal societies are indeed more peaceful internally and in their relations with other liberal democratic states. ${ }^{302}$ Assisting states in becoming more liberal is thus a warranted approach to minimising future conflicts. Furthermore, despite weaknesses in its application, liberal peace operations have not done more harm than good in their host countries. ${ }^{303}$ Given the absence of alternatives and the potential of liberal peace, the approach should be reformed to minimise the negative effects and maximise the extent to which it facilitates long-term peace, rather than discarded.

First, liberal peace should move away from a standardised approach to peacebuilding. Liberal peace has become a formulaic response to post-conflict situations. It uses the same rigid blueprint and even many of the same people for fostering peace in host states. ${ }^{304}$ Yet, formulaic approaches and international 'best practice' are not necessarily the appropriate response to local problems. ${ }^{305} \mathrm{~A}$ standardised model excludes the local population from the reformation process and denies them the right to determine the character of their state and its institutions. ${ }^{306}$ This weakens the foundations of the state as introduced institutions and norms are unlikely to have the necessary grassroots support. If these institutions do not have an impact on local issues, they will fail to become embedded ${ }^{307}$ or may be co-opted by

\footnotetext{
$301 \_$, "Saving Liberal Peacebuilding," 357-59.

$302 \_$_ At War's End: Building Peace after Civil Conflict, 42.

303 _

304 Call and Cousens, "Ending Wars and Building Peace: International Responses to War Torn Societies," 14-15.

${ }^{305}$ Eriksen, "The Liberal Peace Is Neither: Peacebuilding, State Building and the Reproduction of Conflict in the Democratic Republic of Congo," 661. See also Ottaway, "Rebuilding State Institutions in Collapsed States," 248.

306 Eriksen, "The Liberal Peace Is Neither: Peacebuilding, State Building and the Reproduction of Conflict in the Democratic Republic of Congo," 663.

${ }^{307}$ Ottaway, "Rebuilding State Institutions in Collapsed States," 264.
} 
illiberal elite interests. ${ }^{308}$ Moving away from a formulaic approach will allow liberal peace operations to become more responsive and culturally appropriate.

Second, liberal peacebuilders should prioritise learning about the context in which the peace operation is set and the specific needs of the population. This would enable liberal peace to become more nuanced, and broaden its scope from constructing detached liberal structures to creating meaningful structures that are liberal in character but are also culturally relevant. Understanding the specific cultural context of peace operations will also help peacebuilders to identify local paradigms. International efforts to rebuild or reform post-conflict societies should then build on or integrate these paradigms to create more legitimate, durable structures. ${ }^{309}$ Working in close partnership with a host population will also enable the fusion of local and liberal ideas. This synergy or hybridisation will make liberal ideas "domestically relevant" and may even cause local ideas to affect and change international liberal norms. ${ }^{310}$

Greater understanding of the context of a peace mission will concomitantly allow for greater understanding of the specific needs of a population and an increased ability to respond to these. Richmond and Franks accuse liberal peace of prioritising the reformation or construction of institutions which have a limited impact on the lives of the population. ${ }^{311}$ In doing so, liberal peace prioritises rights and overlooks the importance of culture and needs. However, a state is more than its physical infrastructure and the security and dignity of its population should also be advocated and protected. ${ }^{312}$ The population and their everyday experience should therefore be at the centre of peacebuilding; ${ }^{313}$ and improving conditions for ordinary people should be the new top priority of liberal peace. Putting the population first will create greater peace dividends and allow peacebuilders to develop key areas as identified by the population.

\footnotetext{
${ }^{308}$ Snyder, From Voting to Violence: Democratization and Nationalist Conflict, 52.

${ }^{309}$ Hohe, "The Clash of Paradigms: International Administration and Local Political Legitimacy in East Timor," 570.

${ }^{310}$ Richmond, "Liberal Peace Transitions: A Rethink Is Urgent."

${ }^{311}$ Richmond and Franks, "Liberal Hubris? Virtual Peace in Cambodia," 46.

$312 \ldots$, Liberal Peace Transitions: Between Statebuilding and Peacebuilding, 194.

313 Richmond, "Becoming Liberal, Unbecoming Liberalism: Liberal-Local Hybridity Via the Everyday as a Response to the Paradoxes of Liberal Peacebuilding." 6
} 
Third, as Paris argues, ${ }^{314}$ more efforts should be made to strengthen supporting institutions before liberalisation, rather than rushing political and economic reform prematurely. Democracy, capitalism, rule of law, and human rights require a network of public institutions to operate, yet liberal peace takes the existence of a state and supporting structures for granted. ${ }^{315}$ Democracies, for example, require an active civil society, restrictions on state power, public debate, impartial media, and political opposition. ${ }^{316}$ However, many communities emerging from conflict lack the necessary framework to support and sustain a liberal state. ${ }^{317}$ As a result, liberal peacebuilding has created liberal pillars in post-conflict communities which have eroded or been corrupted without the support of institutions.

Liberal peace must abandon its blueprint and identify what institutions are missing or in need of support in a particular setting, before liberalising politics and economics. For democratisation to be a success, Snyder recommends that first a middle class must have developed, followed then by a free and responsible press as well as civic societies - only once these elements are present should democratic elections be held. ${ }^{318}$ International peacebuilders have a role to play in fostering these conditions. Rather than pressing for quick elections, international actors can delay elections until moderate political parties with a degree of popular support have emerged and an impartial judicial system capable of mediating political disputes has been created. ${ }^{319}$ Peacebuilders can also assist in creating an electoral system which fosters cooperation among factions, and encourage or reward good civil society. ${ }^{320}$ Free media could be regulated by international actors until local laws and regulating bodies are created to ensure the press does not become a vehicle for division and hatred. ${ }^{321}$ Finally, economic reforms could be delayed or introduced slowly to create

${ }^{314}$ Paris, At War's End: Building Peace after Civil Conflict. See Chapter 10, 'Toward More Effective Peacebuilding: Institutionalization before Liberalization', 179-211

${ }^{315}$ Ibid., 205.

${ }^{316}$ Snyder, From Voting to Violence: Democratization and Nationalist Conflict, 26.

${ }^{317}$ Paris, At War's End: Building Peace after Civil Conflict, 152.

${ }^{318}$ Snyder, From Voting to Violence: Democratization and Nationalist Conflict, 321.

${ }^{319}$ Paris, At War's End: Building Peace after Civil Conflict, 189-91.

${ }^{320}$ Ibid., 191-95.

${ }^{321}$ Snyder, From Voting to Violence: Democratization and Nationalist Conflict, 63. 
peace dividends and allow for the necessary supporting government and legal institutions to be developed. $^{322}$

To summarise, in this chapter I have argued that while liberal peace is not the panacea it is presented as in the discourse, given the absence of any viable alternative and the link between liberal structures and domestic and international peace, liberal peace should be reformed rather than discarded. In particular, liberal peace should move away from its standardised approach, work in greater cooperation with local populations to determine their specific needs, and focus on strengthening the institutions that will support a liberal society before embarking on liberalisation. The final chapter offers a summary and brief discussion of the challenges for liberal peace reform.

\section{Conclusion}

To conclude, this thesis has provided a critical analysis of liberal peace. In particular, I assessed the extent to which liberal peacebuilding does indeed offer a solution to conflict and social unrest as it claims by undertaking an immanent critique of the liberal peacebuilding efforts in East Timor during the UN administration from 1999 to 2002. The critique found that the methods of liberal peace limit its ability to foster lasting peace.

Liberal peace holds that lasting peace is achievable and necessarily founded on liberal structures. The approach began to dominate peace operations from the 1990s. The end of the Cold War was interpreted as a triumph of liberalism, and without an ideological competitor, liberalism began to spread internationally. Liberal ideology increasingly came to influence politics, economics, and even the character of peace operations. No longer constrained by the superpower standoff, the UN began to envision more robust operations which would end violence and cultivate sustainable peace. A reflection of the UN's new approach, the writings of Boutros-Ghali endorse liberal peace and advocate the identification and support of structures of peace. In

${ }^{322}$ Paris, At War's End: Building Peace after Civil Conflict, 200., 204 
practice, UN peace operations began to focus not just on monitoring and separating conflicting parties, but also on promoting and enabling democracy, free markets, rule of law and human rights.

The UNTAET mission in East Timor was in many ways a classic example of a liberal peacebuilding operation. Given absolute authority over the territory, UNTAET was unrestricted in its pursuit of transforming East Timor into a liberal society capable of supporting lasting peace. Accordingly, UNTAET, with the aid of other international agencies, followed the standard approach to liberal peacebuilding. Elections for a Constituent Assembly and the presidency were scheduled for 2001 and 2002 respectively. Until democratic elections could take place, the amount of power or authority any local body had was limited so as not to influence the upcoming elections. Simultaneously, UNTAET and the World Bank sought to introduce economic reforms that would address subsistence living and the informal economy, improving the conditions for private enterprise and foreign investment. UNTAET was also directed at establishing rule of law and promoting human rights through the reform of the judicial system and security sector.

In 2002, following successful elections, East Timor achieved independence and the UN announced the conclusion of the UNTAET mission. In less than three years, UNTAET claimed to have achieved its goal of creating a liberal state in East Timor. However, while East Timor had the veneer of a liberal democratic state, the immanent critique of the liberal peace process highlighted major problems in each of the four key areas of the UNTAET mission.

These weaknesses either directly led to violence in 2006 , or at the very least, failed to prevent the crisis. Democracy enabled the consolidation of Fretilin's power and failed to end the validity of violence as an expression of political dissatisfaction. Economic reforms did not sufficiently address widespread poverty or unemployment, and failed to create a peace dividend for the population. Unemployment among the youth contributed to the formation of youth gangs who were heavily involved in the protests and violence. Major achievements were made in the judicial sector which receives ongoing support from international experts and enjoys legitimacy in the eyes of the population. However, the police service suffered 
from weak institutional capacity, questionable human rights, and political bias, while the defence force also suffered from weak capacity. The mishandling of soldiers' grievances by defence force elites and the rivalry between the police and defence forces were also major factors in initial emergence of the crisis and in the escalation of violence.

These weaknesses challenge liberal peace's claim that reforming and supporting liberal structures in post-conflict societies will foster lasting peace, and illustrate a number of weaknesses with the approach. In particular, liberal peace can be hierarchical and formulaic, dismissive of local context, and can neglect ordinary citizens and the importance of a peace dividend. Furthermore, the immanent critique demonstrated liberal structures in and of themselves do not automatically guard against the resurgence of violence, and the methods of liberal peacebuilding are as important as the structures being created or reformed.

Despite its limited success and the weaknesses highlighted in the immanent critique, liberal peace should be reformed rather than replaced. Liberal societies are associated with lower rates of conflict internally and with other liberal states, and there is no viable alternative to the liberal peace. Therefore, liberal peacebuilding is a legitimate approach to conflict and has the potential to reduce violence in the long term. In order to minimise the harmful or negative effects of liberal peace, I recommended reforming some of the mechanisms of liberal peace, including: ending the reliance on a standardised approach to peacebuilding; devoting greater attention to the specific context of the operation and the particular needs of a population to ensure the peace created improves the lives of ordinary people; and that institutions should be developed prior to liberalisation.

Liberal peace has already shown a capacity for change. Following the varied results of early liberal peace operations, peacebuilding from the late 1990s turned towards gradual liberalisation and has paid more attention to the institutions that will support liberal structures. ${ }^{323}$ Now is the time for liberal peace to evolve even further.

${ }^{323}$ Ibid., 212 
The challenge lies in changing expectations of policymakers and ensuring ongoing political will. A reformed liberal peace approach will require longer timeframes to achieve its objectives, and donors' expectations of peacebuilding need to become more realistic. Building a liberal state with embedded and locally meaningful structures cannot be achieved in one or two years; it may not even be achieved in ten years. Consequently, reformed liberal peacebuilding will require an open-ended commitment from donors, a commitment policymakers are unlikely to embrace. While long-term commitments may be costly, they are nevertheless more cost effective in the long-run if such operations succeed in fostering sustainable peace. ${ }^{324}$ Meanwhile, donors and peacebuilders will have to change their methods for measuring success. Donor demands for visible results have led practices that do not benefit the greater goal of self-sustaining peace. ${ }^{325}$

These recommendations for liberal peace and donors are a tall order indeed. Advocating change within an industry as enormous as the peace industry is ambitious, and calling on donors to be more generous with resources and less demanding may similarly be dismissed as fanciful. But, while implementing the recommendations is ambitious, so too is the project of lasting peace. ${ }^{326}$ If policymakers are serious about supporting self-sustaining peace they need to have a more accurate appreciation for the complexity of peace, and a more nuanced approach.

\footnotetext{
${ }^{324}$ Ibid., 210.

${ }^{325}$ Richmond and Franks, "Liberal Peacebuilding in Timor Leste: The Emperor's New Clothes?," 194. See also Burton, "Security Sector Reform: Current Issues and Future Challenges," 100.

${ }^{326}$ Snyder, From Voting to Violence: Democratization and Nationalist Conflict, 353.
} 


\section{Bibliography}

Anderson, Tim. "Food Security and Agriculture in the Australia-East Timor Relationship." In East Timor: Beyond Independence, edited by Damien Kingsbury and Michael Leach, 179-90. Clayton: Monash University Press, 2007.

Beauvais, Joel C. "Benevolent Despotism: A Critique of U.N. State-Building in East Timor." New York University Journal of International Law and Politics 33, no. 4 (2000): 1101-77.

Boutros-Ghali, Boutros. "An Agenda for Development: Report of the SecretaryGeneral." United Nations, http://www.un.org/Docs/SG/agdev.html (accessed online 10 December 2010).

—. An Agenda for Peace: Preventative Diplomacy, Peacemaking and PeaceKeeping, Report of the Secretary-General Pursuant to the Statement Adopted by the Summit Meeting of the Security Council on 31 January 1992. New York: United Nations, 1992.

Brady, Cynthia, and David G. Timberman. "The Crisis in Timor-Leste: Causes, Consequences and Options for Conflict Management and Mitigation." USAID, 2006.

Brown, M. Anne. "Security, Development and the Nation-Building Agenda - East Timor." Conflict, Security \& Development 9, no. 2 (2009): 141 - 64.

Burton, Cynthia. "Security Sector Reform: Current Issues and Future Challenges." In East Timor: Beyond Independence, edited by Damien Kingsbury and Michael Leach, 97-109. Clayton: Monash University Press, 2007.

Call, Charles T. "Knowing Peace When You See It: Setting Standards for Peacebuilding Success." Civil Wars 10, no. 2 (2008): 173-94.

Call, Charles T., and Elizabeth M. Cousens. "Ending Wars and Building Peace: International Responses to War Torn Societies." International Studies Perspectives 9, no. 1 (2008): 1-21.

Chan, Steve. "In Search of Democratic Peace: Problems and Promise." Mershon International Studies Review 41, no. 1 (1997): 59-91.

Chopra, Jarat. "Building State-Failure in East Timor." Development and Change 33, no. 5 (2002): 979-1000.

. "The U.N's Kingdom of East Timor." Survival 42, no. 3 (2000): 27-40.

David, Charles-Philippe. "Does Peacebuilding Build Peace? Liberal (Mis)Steps in the Peace Process." Security Dialogue 30, no. 1 (1999): 25-41.

Diehl, Paul F. Peace Operations. Cambridge: Polity Press, 2008.

Downie, Sue. "U.N.T.A.E.T: State-Building and Peace-Building." In East Timor: Beyond Independence, edited by Damien Kingsbury and Michael Leach, 2942. Clayton: Monash University Press, 2007.

Doyle, Michael W. "Kant, Liberal Legacies, and Foreign Affairs." Philosophy and Public Affairs 12, no. 3 (1983): 205-35.

-. "Liberalism and International Relations." In Kant and Political Philosophy: The Contemporary Legacy, edited by Ronald Beiner and William James Booth, 173-203. New Haven: Yale University Press, 1993.

Elliott, Paul D. "The East Timor Dispute." International and Comparative Law Quarterly 27, no. 01 (1978): 238-49. 
Eriksen, Stein Sundstøl. "The Liberal Peace Is Neither: Peacebuilding, State Building and the Reproduction of Conflict in the Democratic Republic of Congo." International Peacekeeping 16, no. 5 (2009): 652-66.

Fox, James J. "Tracing the Path, Recounting the Past: Historical Perspectives on Timor." In Out of the Ashes: Destruction and Reconstruction of East Timor, edited by James J. Fox and Dionisio Babo Soares, 1-29. Hindmarsh: Crawford House Publishing, 2000.

Goulding, Marrack. "The Evolution of U.N. Peacekeeping " International Affairs 69, no. 3 (1993): 451-64.

Heathershaw, John. "Unpacking the Liberal Peace: The Dividing and Merging of Peacebuilding Discourses." Millennium 36, no. 3 (2008): 597-621.

Hill, Hal, and Takashi Shiraishi. "Indonesia after the Asian Crisis." Asian Economic Policy Review 2, no. 1 (2007): 123-41.

Hohe, Tanja. "The Clash of Paradigms: International Administration and Local Political Legitimacy in East Timor." Contemporary Southeast Asia 24, no. 3 (2002): 569-89.

Hood, Ludovic. "Security Sector Reform in East Timor, 1999-2004." International Peacekeeping 13, no. 1 (2006): 60 - 77.

International Crisis Group. "Resolving Timor-Leste's Crisis." Asia Report 120, (2006).

_. "Timor-Leste: Security Sector Reform." Asia Report 143, (2008).

Kant, Immanuel. Perpetual Peace: A Philosophical Sketch. New York: Cosimo, 2005.

Kingsbury, Damien. "Political Development." In East Timor: Beyond Independence, edited by Damien Kingsbury and Michael Leach, 19-27. Clayton: Monash University Press, 2007.

Kingsbury, Damien, and Michael Leach. "Introduction." In East Timor: Beyond Independence, edited by Damien Kingsbury and Michael Leach, 1-16. Clayton: Monash University Press, 2007.

Kostner, Markus, and Samuel Clark. "Timor-Leste's Youth in Crisis: Situational Analysis and Policy Options." World Bank, http://go.worldbank.org/8MR7LHVIX0 (accessed 17 January 2011).

Layne, Christopher. "Kant or Cant: The Myth of the Democratic Peace." International Security 19, no. 2 (1994): 5-49.

Leaver, Richard. "Introduction: Australia, East Timor and Indonesia." The Pacific Review 14, no. 1 (2001): 1-14.

Mac Ginty, Roger. "Indigenous Peace-Making Versus the Liberal Peace." Cooperation and Conflict 43, no. 2 (2008): 139-63.

Mac Ginty, Roger, and Oliver P. Richmond. "Myth or Reality: Opposing Views on the Liberal Peace and Post-War Reconstruction." Global Society 21, no. 4 (2007): 491-97.

Mandelbaum, Michael. The Ideas That Conquered the World: Peace Democracy, and Free Markets in the Twenty-First Century. New York: Public Affairs, 2002.

Mansfield, Edward D., and Jack L. Snyder. "The Sequencing 'Fallacy'." Journal of Democracy 18, no. 3 (2007): 5-10.

Martin, Ian, and Alexander Mayer-Rieckh. "The United Nations and East Timor: From Self-Determination to State-Building." International Peacekeeping 12, no. 1 (2005): $125-45$. 
Nevins, Joseph. "The Making Of "Ground Zero" In East Timor in 1999." Asian Survey 42, no. 4 (2002): 623-41.

Niner, Sara. "Martyrs, Heroes and Warriors: The Leadership of East Timor." In East Timor: Beyond Independence, edited by Damien Kingsbury and Michael Leach, 113-28. Clayton: Monash University Press, 2007.

Ottaway, Marina. "Rebuilding State Institutions in Collapsed States." In State Failure, Collapse and Reconstruction, edited by Jennifer Milliken, 245-66. Malden: Blackwell Publishing, 2003.

Owen, John M. "How Liberalism Produces Democratic Peace." International Security 19, no. 2 (1994): 87-125.

Paris, Roland. At War's End: Building Peace after Civil Conflict. Cambridge: Cambridge University Press, 2004.

_. "Peacebuilding and the Limits of Liberal Internationalism." International Security 22, no. 2 (1997): 54-89.

__. "Saving Liberal Peacebuilding." Review of International Studies 36, no. 2 (2010): 337-65.

Paulo, Gorjao. "The Legacy and Lessons of the United Nations Transitional Administration in East Timor." Contemporary Southeast Asia 24, no. 2 (2002): 313-36.

Richmond, Oliver P. "Becoming Liberal, Unbecoming Liberalism: Liberal-Local Hybridity Via the Everyday as a Response to the Paradoxes of Liberal Peacebuilding." $\quad$ http://www.standrews.ac.uk/intrel/media/becoming_liberal.pdf (accessed 20 January 2011).

_ . "Liberal Peace Transitions: A Rethink Is Urgent." Open Democracy http://www.opendemocracy.net/oliver-p-richmond/liberal-peace-transitionsrethink-is-urgent (accessed 23 November 2010).

_. "The Problem of Peace: Understanding the 'Liberal Peace'." Conflict, Security and Development 6, no. 3 (2006): 291-314.

Richmond, Oliver P., and Jason Franks. "Liberal Hubris? Virtual Peace in Cambodia." Security Dialogue 38, no. 1 (2007): 27-48.

- Liberal Peace Transitions: Between Statebuilding and Peacebuilding. Edinburgh: Edinburgh University Press, 2009.

_. "Liberal Peacebuilding in Timor Leste: The Emperor's New Clothes?" International Peacekeeping 15, no. 2 (2008): 185 - 200.

Schwarz, Adam. "East Timor: The Little Pebble That Could." In A Nation in Waiting: Indonesian in the 1990s. Boulder: Westview Press, 1994.

Simonsen, Sven Gunnar. "The Authoritarian Temptation in East Timor: Nationbuilding and the Need for Inclusive Governance." Asian Survey 46, no. 4 (2006): 575-96.

Snyder, Jack. From Voting to Violence: Democratization and Nationalist Conflict. New York: Norton, 2000.

Strohmeyer, Hansjorg. "Collapse and Reconstruction of a Judicial System: The United Nations Missions in Kosovo and East Timor." The American Journal of International Law 95, no. 1 (2001): 46-63.

Suhrke, Astri. "Peacekeepers as Nation-Builders: Dilemmas of the U.N in East Timor." International Peacekeeping 8, no. 4 (2001): 1 - 20.

Taylor-Leech, Kerry. "Sustaining Language Policy and Language Rights: Where to from Here." In East Timor: Beyond Independence, edited by Damien 
Kingsbury and Michael Leach, 239-50. Clayton: Monash University Press, 2007.

Traub, James. "Inventing East Timor." Foreign Affairs 79, no. 4 (2000): 74-89.

Trust Fund for East Timor (TFET). "Report of the Trustee Technical Appendix: Project Overviews." World Bank, http://siteresources.worldbank.org/INTTIMORLESTE/Resources/TFETTechnical-Appendix final.pdf (accessed 23 February 2011).

United Nations General Assembly. "Question of Timor." GA Res. 3485 (XXX), UNGAOR, 30th Sess., Supp. 34, U.N. Doc. A/10034, pg 118, 1975.

United Nations Security Council. "Report of the Secretary-General: The Rule of Law and Transitional Justice in Conflict and Post-Conflict Societies." http://www.unrol.org/files/2004\%20report.pdf (accessed 09 January 2011).

. "The Situation in East Timor." SC Res. 1272, UN SCOR, 54th sess, U.N. Doc. S/INF/55, pg 1301999.

Wheeler, Nicholas J., and Tim Dunne. "East Timor and the New Humanitarian Interventionism." International Affairs 77, no. 4 (2001): 805-27.

Wigglesworth, Ann. "Young People in Rural Development." In East Timor: Beyond Independence, edited by Damien Kingsbury and Michael Leach, 51-64. Clayton: Monash University Press, 2007.

World Bank. "Closing Press Conference in Timor-Leste with Paul Wolfowitz." http://go.worldbank.org/XOGCSIM1H0 (accessed 07 February 2011).

"Timor-Leste Data." http://data.worldbank.org/country/timor-leste (accessed 20 January 2011).

_- "Timor-Leste: Economic and Social Development Brief." World Bank, http://go.worldbank.org/RZF7BL1H60 (accessed 10 January 2011). 